\title{
An update on the prone position: Continuing Professional Development
}

\author{
Jason Chui, MBChB $\cdot$ Rosemary Ann Craen, MBBS
}

Received: 6 July 2015/Revised: 8 February 2016/Accepted: 15 March 2016/Published online: 12 April 2016

(c) Canadian Anesthesiologists' Society 2016

\begin{abstract}
Purpose The purpose of this Continuing Professional Development module is to provide information needed to prepare for and clinically manage a patient in the prone position. Principal findings Prone positioning is required for surgical procedures that involve the posterior aspect of a patient. We searched MEDLINE ${ }^{\circledR}$ and $E M B A S E^{T M}$ from January 2000 to January 2015 for literature related to the prone position and retrieved only original articles in English. We reviewed the advantages and disadvantages of various equipment used in prone positioning, the physiological changes associated with prone positioning, and the complications that can occur. We also reviewed strategies for the safe conduct and management of position-related complications.

Conclusion Increased age, elevated body mass index, the presence of comorbidities, and long duration of surgery appear to be the most important risk factors for complications associated with prone positioning. We recommend a structured team approach and careful selection of equipment tailored to the patient and surgery. The systematic use of checklists is recommended to guide operating room teams and to reduce prone position-related complications. Anesthesiologists should be prepared to manage major intraoperative emergencies (e.g., accidental extubation) and anticipate postoperative complications (e.g., airway edema and visual loss).
\end{abstract}

This manuscript was screened for plagiarism using iThenticate.

Ce manuscrit a été examiné à l'aide d'iThenticate pour dépister tout plagiat.

J. Chui, MBChB $\cdot$ R. A. Craen, MBBS $(\square)$

Department of Anesthesia \& Perioperative Medicine, Schulich

School of Medicine, Western University, 339 Windermere Road,

London, ON N6A 5A5, Canada

e-mail: rosemary.craen@lhsc.on.ca

\section{Objectives}

After reading this module, the anesthesia provider should be able to:

1. Identify the various types of equipment used in prone positioning, including their indications, advantages, and disadvantages.

2. Describe the physiological changes associated with prone positioning, especially its effects on the cardiorespiratory system.

3. Understand the potential complications that can occur with prone positioning and describe techniques to prevent or manage them.

4. Formulate a strategy for planned extubation after prolonged prone positioning.

5. Describe the management of an accidental extubation during prone positioning.

6. Discuss strategies to improve the safety of patients undergoing surgery in the prone position.

The prone position has been used to provide posterior surgical access in a wide variety of operations since the 1930s. Common surgical procedures involving the prone position include neurosurgery (e.g., posterior fossa and posterior spine), urological procedures (e.g., nephrostomy, litholapaxy), general surgery (especially anorectal), plastics (e.g., debridement of sacral ulcers), and orthopedic procedures (e.g., Achilles tendon repair). A large variety of equipment is used for positioning, including tables, supports, arm boards, headrests, and head clamps (Tables 1, 2). In most cases, the choice of equipment is driven by surgeons' preferences. Nevertheless, due to the increasing complexity of surgeries and the increasing age and body weight of patients, equipment modifications have been made over the 
years to help reduce patient complications and injuries. The published medical literature has focused mainly on the physiological effects and complications associated with the prone position. In this Continuing Professional Development module, we review the physiological effects associated with turning a patient prone and the advantages and disadvantages of the various types of equipment used in prone positioning. We also review strategies for the safe conduct and management of positionrelated complications.

\section{Physiological changes associated with the prone position}

\section{Effects on the respiratory system}

Distribution of ventilation and perfusion in humans is largely governed by the intrinsic bronchoalveolar architecture and, to a lesser degree, the effects of gravity on ventilation (V) and blood flow (Q). ${ }^{1}$ When healthy anesthetized patients are supine, perfusion is preferentially distributed to the dorsal (posterior) alveoli due to a lower intrinsic pulmonary vascular resistance, whereas ventilation is preferentially distributed to the mid-todorsal alveoli because of the structural features of the airways. ${ }^{2}$ When patients are turned prone, gravity partially opposes the higher pulmonary vascular resistance in the ventral (anterior) alveoli and partially reverses the distribution of perfusion. As a result, perfusion is distributed more uniformly (or equally) from the dorsal to ventral areas in the prone position, while the distribution of ventilation is largely unchanged by gravitational forces. Overall, V/Q mismatch is reduced, resulting in improved arterial oxygenation. However, if positive end-expiratory pressure (PEEP) is applied $\left(>10 \mathrm{~cm} \mathrm{H}_{2} \mathrm{O}\right)$, blood flow is further redistributed from the dorsal to the ventral areas, increasing V/Q mismatch and resulting in a paradoxical reduction in arterial oxygenation. ${ }^{3}$ The reduction in arterial oxygenation is often clinically insignificant in healthy anesthetized patients positioned prone, and the routine use of PEEP is unnecessary and not recommended for the majority of anesthetized patients in the prone position.

In contrast, in patients with severe acute respiratory distress syndrome (ARDS), adoption of the prone position leads to recruitment of dorsal (posterior) alveoli and derecruitment of ventral (anterior) alveoli, without significant alteration to perfusion in low PEEP conditions. ${ }^{4}$ The addition of PEEP $\left(>10 \mathrm{~cm} \mathrm{H}_{2} \mathrm{O}\right)$ results in a redistribution of blood flow that matches the redistributed ventilation, resulting in even higher oxygenation. ${ }^{4}$ Thus, prone positioning has been used to improve oxygenation in severe ARDS patients and has been shown to improve survival in the critical care setting (relative risk reduction of death, $16 \%)^{5}$

Changes in lung mechanics are minimal in healthy anesthetized patients positioned prone. While the total resistance of the respiratory system has been reported to increase by $20 \%$, airway resistance does not change in the prone position. ${ }^{1,6}$ Interestingly, the reduction in functional residual capacity seen in prone anesthetized patients is less than that seen in supine anesthetized patients $(-12 \%$ vs $-44 \%$, respectively). ${ }^{1}$ It is important to point out, however, that these findings of largely unchanged lung mechanics were found with meticulous and optimal prone positioning during the conduct of the original studies.

\section{Effects on the cardiovascular system}

The cardiovascular physiological effects of prone positioning have been documented since the early 1990s. Earlier studies using pulmonary artery catheters and more recent studies using transesophageal echocardiography (TEE) consistently showed a $10-20 \%$ reduction in cardiac index (CI) in healthy anesthetized patients in the prone position. ${ }^{7}$ The causes include decreased pre-load due to inferior vena cava compression and/or reduced left ventricular (LV) compliance due to increased intrathoracic pressures. Systemic vascular resistance is largely unchanged. In a TEE study of healthy patients undergoing lumbar laminectomy, the authors confirmed a significant reduction in LV end-diastolic area and systolic blunting of the pulmonary venous flow, reflecting an acute reduction in LV filling pressures. ${ }^{7}$ In healthy patients, these changes were largely compensated by increases in cardiac contractility and LV ejection fraction. Overall, despite the mild reduction in $\mathrm{CI}$, systolic blood pressure and heart rate remained unchanged. ${ }^{8}$ It is important to emphasize that these minor cardiovascular changes were observed in healthy patients who were meticulously positioned prone, meaning that bolsters did not compromise major vessels and impede venous return. Significant hemodynamic changes can be expected if patients have an increased body mass index (BMI), cardiac or respiratory comorbidities, and/or are suboptimally positioned. In a study using a single-photon emission computed tomography scan, the authors investigated the effects of prone positioning on cardiac function in awake patients with a history of myocardial infarction or ischemic heart disease. ${ }^{9}$ The authors found a significant reduction in CI and LV ejection fraction in all patients. These reductions in CI were more marked in patients with pre-existing systolic dysfunction. ${ }^{9}$

It is not uncommon to encounter patients with poor cardiac function or complex cardiac issues requiring surgery in the prone position. There have been case 
Table 1 Commonly used equipment for prone position

\begin{tabular}{|c|c|c|c|}
\hline Types & Description & Advantages & Disadvantages \\
\hline & $\begin{array}{l}\text { - Laterally adjustable gel pads to } \\
\text { reduce chest compression } \\
\text { - Contains crank mechanism to reduce } \\
\text { lumbar lordosis }\end{array}$ & $\begin{array}{l}\text { Claims to reduce surgical bleeding } \\
\text { and improve surgical access, } \\
\text { particularly with transforaminal } \\
\text { lumbar inter-body fusion procedures }\end{array}$ & $\begin{array}{l}\text { - Increase POVL (? due to } \\
\text { head-down position) } \\
\text { - Partial abdominal } \\
\text { compression } \\
\text { - Increased pressure on } \\
\text { large or pendulous } \\
\text { breasts }\end{array}$ \\
\hline
\end{tabular}

Wilson Frame

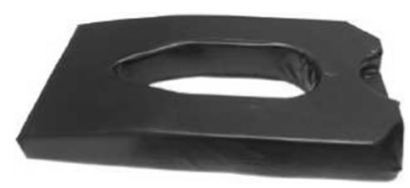

Montreal Mattress

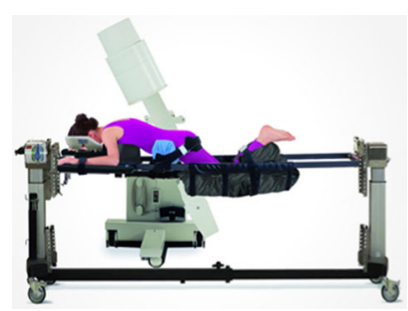

- Adjustable chest and abdominal supports

- Arms can be abducted $90^{\circ}$ or tucked by side

- Legs at or below the level of the heart
- Convenient

- Usually padded with additional gel pads to avoid pressure-related injuries.

- Central cavity allows abdominal decompression
- Acceptable abdominal and chest compression in non-obese patient

- Abdominal compression in obese patients

- Reports of pressurerelated injuries in short and obese patient at bony prominences

- Table can be axially rotated $180^{\circ}$

- Cost

Jackson Table

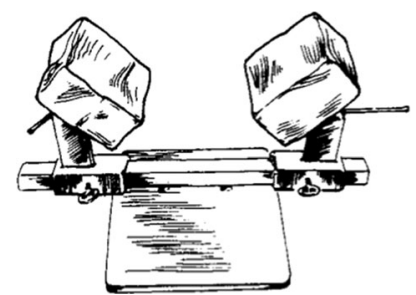

- Four individually adjustable supports in two Vshaped pairs tilting inwards to support lateral thoracic cage and anterolateral pelvis
- Reduces intra-abdominal pressure

- Tends to correct scoliosis

- Adjustable for any body habitus and degree of scoliosis

- Very stable

- Can be modified to allow skeletal traction
- Increases lumbar lordosis (unsuitable for disc surgery)

Relton and Hall Frame

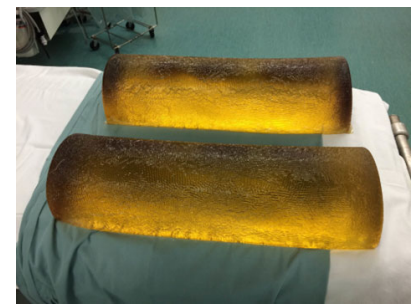

Bolsters can be made of gel, rolled foam, or blankets
- Cheap

- Easily available

- Size can be modified according to body habitus
- Partial compression of chest and abdomen

Gel/Foam Bolsters 
Table 1 continued

\begin{tabular}{ll} 
Types & Description \\
\hline & $\begin{array}{l}\text { Airtight flexible mattress } \\
\text { Becomes rigid on evacuation and } \\
\text { can be moulded to support iliac } \\
\text { crests and thorax, leaving the } \\
\text { abdomen free }\end{array}$
\end{tabular}

Evacuable Mattress (bean bag)

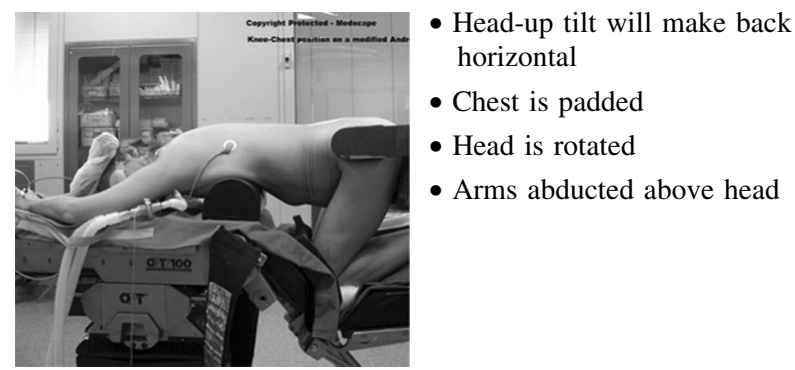

Advantages

- Less pressure effects (spreads load over whole body)

- Adjustable for any body habitus

- Heat-retaining

Disadvantages

- No access to anterior chest wall (for resuscitation)

- Rigidity of surface (with air evacuation) can increase the risk of pressure-related injuries

- Excellent abdominal decompression, reduces venous engorgement

- Labour intensive, unstable position

- Weight borne on ischial tuberosities (not knees)

- Reduces risk of crush injury to legs and deep venous thrombosis

- Ventilation is good but cardiac output drops significantly

- Compartment syndrome of gluteal muscles and legs due to excessive hip/knee flexion

Knee-Chest device (for knee-chest position)

POVL = postoperative visual loss

Modified and reproduced with permission from: Edgcombe H, Carter K, Yarrow S. Anaesthesia in the prone position. Br J Anaesth 2008; 100: 165-83

Pictures of Relton-Hall Frame and Evacuable Mattress are reproduced with permission from: Wadsworth R, Anderton JM, Vohra A. The effect of four different surgical prone positions on cardiovascular parameters in healthy volunteers. Anaesthesia 1996; 51: 819-22

Picture of Knee-chest devices are reproduced with permission from: Rigamonti A, Gemma M, Rocca A, Messina M, Bignami E, Beretta L. Prone versus knee-chest position for microdiscectomy: a prospective randomized study of intra-abdominal pressure and intraoperative bleeding. Spine (Phila Pa 1976) 2005; 30: 1918-23

reports of elective surgery in the prone position on patients with severe aortic stenosis ${ }^{10}$ or a $\mathrm{LV}$ assist device. ${ }^{11}$ As there is a wide variety of cardiac diseases with impaired systolic and diastolic function, it is difficult to predict the hemodynamic consequences of turning such patients prone during anesthesia. As a general rule, all patients who are preload dependent or have low cardiac contractile reserve or pre-existing diastolic dysfunction are at risk of hemodynamic compromise during prone positioning. These patients should be carefully evaluated preoperatively and consideration given to the use of invasive pressure monitoring intraoperatively.

\section{Anesthetic management during prone positioning}

This section discusses the preparation and management of patients undergoing procedures in the prone position. The following approach is suggested in such cases: determine a patient's suitability for prone positioning; prepare the equipment (including table and headrests); anticipate the adverse hemodynamic and ventilatory changes that may occur; and follow a checklist for positioning and safe extubation to minimize complications.

Preoperative assessment

The preoperative assessment should identify patients with comorbidities associated with position-related complications. Patient-related risk factors include decreased neck mobility, fixed cardiac outflow obstruction, pulmonary hypertension, chronic airflow obstruction, and morbid obesity with large abdominal pannus. A careful history and physical examination should include checking for the presence and severity of these conditions. In addition, careful attention should be paid to neck and joint mobility (especially shoulders, elbows, and hips) and the presence of significant kyphosis. Positionrelated symptoms, such as those seen with cervical spine stenosis or thoracic outlet syndrome, should be explored. Patients who will be positioned with their arms extended overhead should be able to comfortably demonstrate this "surrender position" preoperatively. If a patient is unable to do so due to paresthesia, numbness, or restricted 


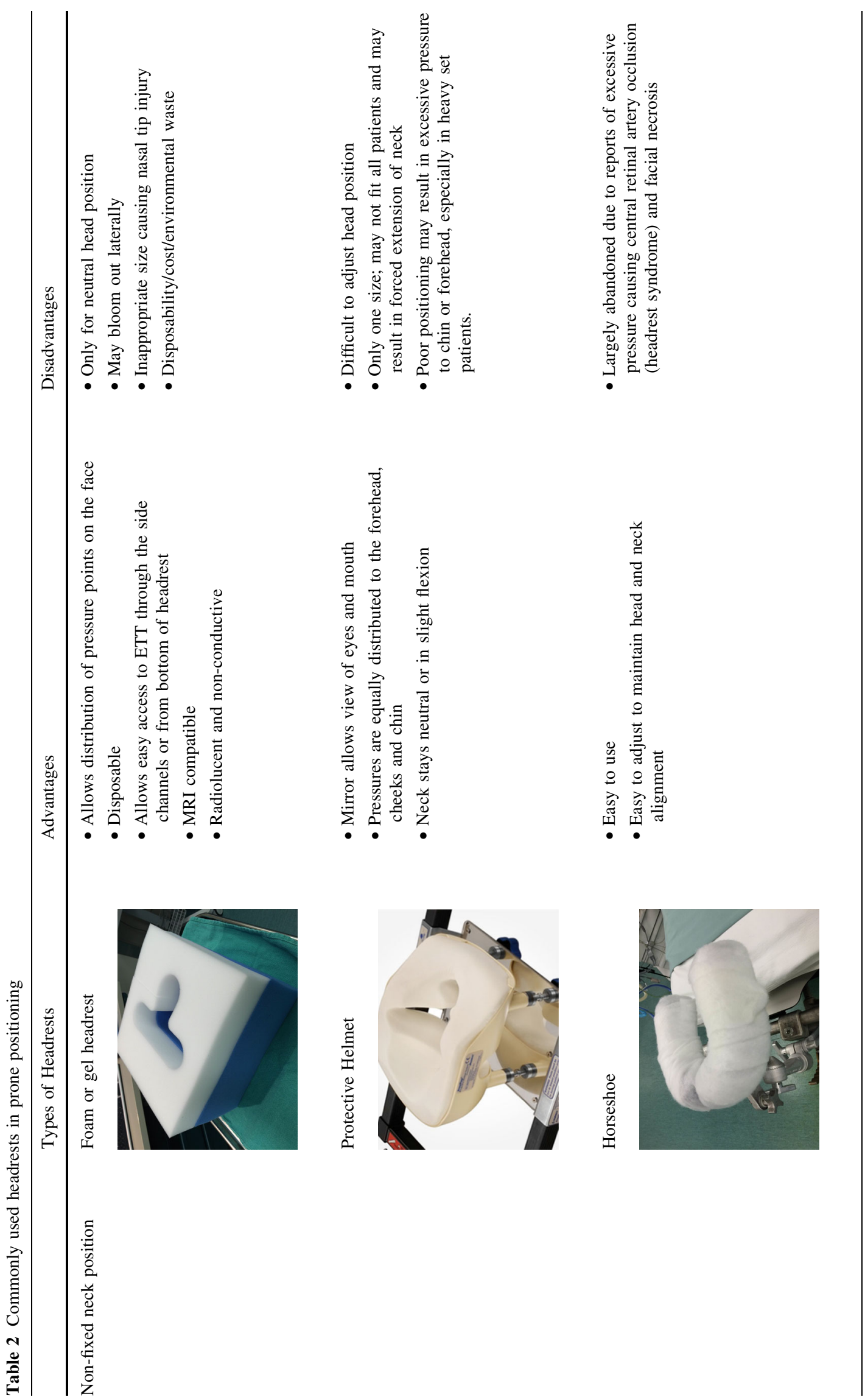




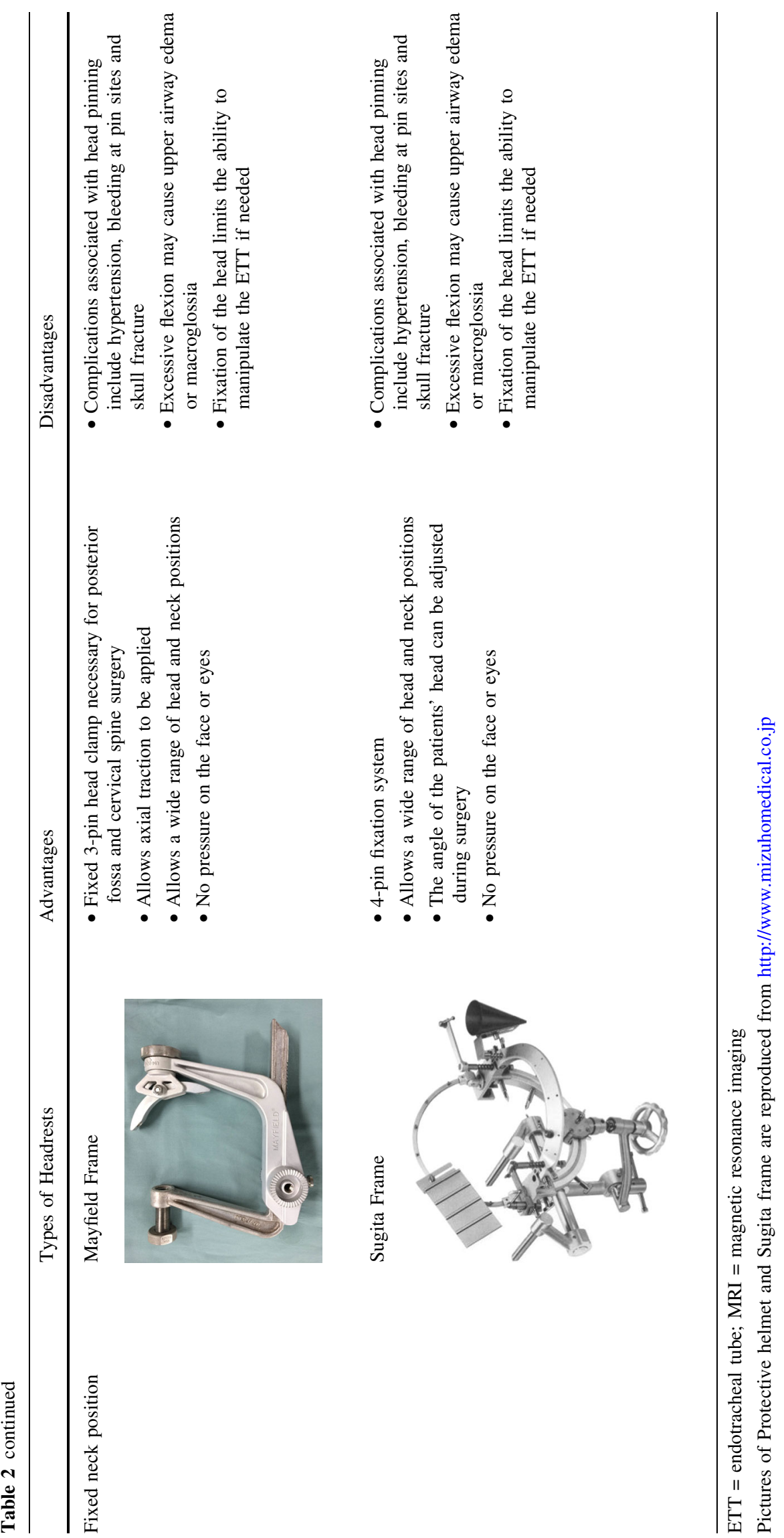


mobility, the possibility of tucking the adducted arms should be considered. Finally, the presence of breast implants, pacemakers, or ostomy bags should be noted, as these may require additional care and padding. If concerns are high regarding prone positioning, the feasibility of doing the procedure using an alternative position, such as the lateral or lithotomy position, should be considered and discussed with the surgeon before proceeding with positioning.

\section{Induction / airway management}

The most commonly used airway management strategy for patients requiring prone positioning is first to perform tracheal intubation with the patient in the supine position before turning to the prone position. It has been proposed that placing an awake patient in the prone position prior to induction of general anesthesia is a way to reduce airway and pressure-related injuries. In a recently published randomized-controlled trial comparing induction in the supine position (with endotracheal intubation) $v s$ in the prone position (with insertion of a supraglottic airway [SGA]), the only benefit found was a statistically, albeit not clinically, significant reduction in time to readiness for commencement of surgery (25 $\mathrm{min} v s 30 \mathrm{~min}$, respectively; $P<0.001){ }^{12}$ Potential loss of the airway, limited choices in airway devices and airway maneuvres, and adverse hemodynamics are the major deterrents to the induction of anesthesia in the awake prone patient. ${ }^{13}$ On the other hand, patients with an unstable spine may be at risk of further neurological injury while anesthetized during prone positioning. The preferred approach in these patients may be to secure the airway awake with the patient in the supine position, followed by prone positioning and repeat neurological testing before induction of anesthesia (with the patient prone). ${ }^{14,15}$

\section{Ventilation strategy}

There should be minimal changes in lung mechanics and gas exchange if healthy patients are correctly positioned prone. Nevertheless, poor chest wall compliance and high airway pressures are commonly observed in patients who are poorly positioned, a fact that highlights the consideration for intraoperative spirometry. The negative effects of prone positioning on lung mechanics can be more significant in patients with preexisting lung disease, reduced exercise tolerance, or morbid obesity, but the magnitude of these changes can be reduced with careful positioning. ${ }^{16}$

In a study comparing pressure-controlled ventilation with volume-controlled ventilation in patients undergoing lumbar spine surgery, lower peak airway pressures were found using pressure-controlled ventilation while achieving similar minute ventilation and end-tidal carbon dioxide levels. ${ }^{17}$ However, the study found no difference in the incidence of acute lung injury or barotrauma between the two ventilator modes.

\section{Hemodynamic management}

Meticulous positioning to reduce thoracic and abdominal pressure is the key to minimizing adverse hemodynamic changes in the prone position. In clinical practice, the majority of healthy patients tolerate the prone position well, and this has led to the false impression that prone positioning is not associated with significant hemodynamic changes. However, hemodynamic compromise is more pronounced in patients with increased thoracic and abdominal pressure, truncal obesity, or when prone positioning is modified to improve surgical access (e.g., exaggerated lumbar flexion on the Wilson frame or in the knee-chest position). ${ }^{18}$ Reverse Trendelenburg positioning is also associated with hemodynamic compromise due to venous pooling in the lower extremities.

In addition to the application of standard patient monitoring, ${ }^{19}$ invasive arterial blood pressure monitoring should be used in patients with cardiorespiratory compromise, morbid obesity, as well as in prolonged operations and in procedures where significant blood loss is expected. Noninvasive cardiac output monitoring or TEE may also be useful in selected patients. Noninvasive cardiac output monitoring devices based on stroke volume or pulse pressure variation have been validated to predict fluid responsiveness in the prone position. ${ }^{20}$ The use of TEE in the prone position has been hindered by limited probe movement and echocardiographic views, as well as cumbersome ergonomics, and concerns about tongue and oropharyngeal pressure injuries in prolonged procedures. It may be extremely difficult to insert a TEE probe after the patient has been turned into the prone position, especially if the head is fixed in a Mayfield clamp. As a result, this limits the usefulness of TEE for the evaluation of unexplained intraoperative hemodynamic compromise.

While the patient is in the prone position, the hemodynamic goals are to maintain sinus rhythm and normal heart rates (albeit at the upper limits), to ensure adequate LV diastolic volume, and to maintain cardiac contractility. Routine volume preloading of patients has been shown to reduce the hypotensive effects of the prone position. ${ }^{21}$ In some patients, inotropic agents may be indicated to maintain the $\mathrm{CI}$ and the coronary and cerebral perfusion pressures. If the patient becomes hemodynamically unstable after being turned prone, the stretcher on which they were induced should remain in the operating room (OR) until the vitals have been stabilized 
in order to accommodate them being transiently returned to the supine position if need be.

Few studies have addressed the choice of anesthetic agents for procedures in the prone position. In one of the handful of studies that is available, the hemodynamic effects of propofol $v s$ isoflurane in healthy patients in the prone position were compared and showed that propofol anesthesia was associated with a greater reduction in CI $\left(0.7 \mathrm{~L} \cdot \mathrm{min}^{-1} \cdot \mathrm{m}^{-2}\right.$ vs $0.4 \mathrm{~L} \cdot \mathrm{min}^{-1} \cdot \mathrm{m}^{-2}$, respectively; $P=$ $0.001) .^{22}$ Furthermore, there is a similar paucity of studies looking at the effects of different anesthetic agents in patients with preexisting cardiac diseases undergoing surgery in the prone position.

\section{Extubation after surgery in the prone position}

There have been reports of airway mishaps and near misses following planned tracheal extubation in patients who had been positioned prone. ${ }^{23-26}$ The reported reasons for loss of airway patency and failure to re-establish the airway include macroglossia, supraglottic/laryngeal edema, direct surgical trauma to the paratracheal soft tissues (during posterior cervical spine surgeries), and traction/trauma to the salivary ducts (resulting in pharyngeal swelling). Upper airway edema and macroglossia can result from local compression (e.g., oral airways), venous or lymphatic obstruction (from neck rotation/hyperflexion), and tissue hypoperfusion due to systemic hypotension. In addition, edematous tissues bleed easily during attempts to re-establish the airway. Finally, coughing and laryngospasm can further compromise the upper airway.

Prolonged surgery and large fluid shifts are associated with increased upper airway edema. There is a lack of studies examining whether the use of colloid $v s$ crystalloid affects the severity of airway edema. Where possible, reverse Trendelenburg in the prone position may reduce face and airway edema and intraocular pressure while improving respiratory mechanics.

Guidelines have been published on safety when conducting tracheal extubation, and on the management of extubation failures. ${ }^{26,27}$ The decision to delay extubation should be based on an individualized risk assessment after considering patient and surgical factors. Results of a retrospective study of posterior craniotomies showed that higher American Society of Anesthesiologists' (ASA) physical status, longer duration of surgery, greater blood loss, and larger volumes of crystalloid replacement were all associated with the decision to delay extubation. ${ }^{28}$ If early extubation is desired, the anesthesiologist should determine the likelihood of a successful extubation and have a plan for extubation and re-intubation, if required (Table 3). It is worth mentioning that upper airway edema (or obstruction) can continue to develop up to $12 \mathrm{hr}$ after extubation, hence the need to monitor these patients closely after extubation.

\section{Complications and their management}

\section{Complications related to changing position}

Turning the patient prone is often accompanied by a temporary loss of patient monitoring, and can be associated with dislodgement of the endotracheal tube (ETT) and other intravenous or arterial catheters. Oxygen desaturation may occur during the subsequent unventilated period; maintaining patients on $100 \% \mathrm{O}_{2}$ before position change can mitigate this problem by providing more oxygen reserves. Temporary disconnection of the breathing circuit also interrupts the delivery of inhaled anesthetics and can increase the risk of patient awareness. In addition, physical injuries to the patient and staff may occur during positioning. It is important to provide adequate and specific training to all members of the OR team to reduce the risk of this occuring.

\section{Resuscitation in the prone position}

There are several case reports describing successful patient resuscitation in the prone position. The approach to resuscitating patients in the prone position is largely similar to that in the supine position. Though the general guidelines and algorithms for basic and advanced life support are the same, there are some key differences in the methods of performing external cardiac compression and defibrillation in the prone patient.

Results of two small clinical studies showed that external cardiac compression in the prone position can produce a slightly higher systolic and diastolic blood pressure when compared with the supine position. ${ }^{29,30}$ Although there is no conclusive evidence or consensus regarding the conduct of resuscitation in the prone position, it is generally accepted that resuscitation should be initiated immediately, before packing the surgical site and turning the patient back to the supine position. Chest compression can be performed on the posterior thoracic spine at levels between the scapulae. Counter pressure can be applied (e.g., putting a fist under the sternum) in patients positioned with bolsters, padding, or the Jackson table. (Fig. 1) The effectiveness of chest compression may be reduced in patients on the Wilson frame or Montreal frame because of the limited access for counter pressure. ${ }^{31,32}$

Defibrillation pads or paddles can be placed in the anterior-posterior position; however, the impact on impedance or the effectiveness of defibrillation (or cardioversion) is not fully known. For patients at risk of 
Table 3 Strategies for safe extubation after prone positioning

Questions to ask before tracheal extubation

Surgical factors

- Was surgery duration $>$ than $12 \mathrm{hr}$ ?

- Was there a large volume of blood loss or fluid shifts (e.g., $>4$ units of packed cell transfusion)?

- If acute $\mathrm{C}$-spine fracture, is there a possibility of paravertebral hematoma which could compromise airway calibre?

- Is there a need for early neurological examination, or can I delay extubation?

Patient factors

- Are there significant cardiopulmonary comorbidities?

- Is the patient morbidly obese?

Anesthetic factors

- Was it a difficult or traumatic intubation at the start of the case?

- Is there a history of difficult intubation?

- How severe is the facial, tongue, and airway edema?

- Is the patient currently hemodynamically stable?

- Is the patient fully reversed from neuromuscular blockade?

- Will it be difficult to bag-mask ventilate after extubation?

- Will it be difficult to reintubate after extubation?

- Is skilled staff available to assist in reintubating this patient's trachea?

Equipment factors

Do I have a tracheal tube exchanger?

Do I have backup airway devices in the operating room (OR) (e.g., supraglottic device, fibreoptic bronchoscope, GlideScope ${ }^{\circledR}$ )?

Check airway patency

- Perform direct laryngoscopy to assess extent of upper airway edema.

- Conducting a leak test around the endotracheal tube (ETT) with the cuff deflated may help determine the likelihood of a successful extubation in the spontaneously breathing patient. However, the tests focus on the assessment of laryngeal edema and therefore may not be useful in cases of tongue and supraglottic edema.

Positive pressure leak test: While performing lung insufflation, deflate cuff pilot balloon and listen for air leak around the ETT. Air leak should occur at pressures less than $15-20 \mathrm{~cm} \mathrm{H}_{2} \mathrm{O}$. To measure insufflation pressures outside the OR, insert a pressure gauge into the patient circuit. Alternatively, with lung insufflation, use a spirometer to observe the differences between inspired and expired tidal volumes with the cuff pilot balloon deflated. If the difference is $>110 \mathrm{~mL}$, this is a reasonable indication of airway patency.

Negative pressure leak test: Deflate cuff pilot balloon, detach ETT from circuit and simultaneously occlude ETT; watch for respiratory excursions. If no respiratory movement is seen, the test has failed.

- Ultrasound (US)

US may help assess the diameter of the air column within the larynx.

Management of equivocal cases

- Prepare for the reintubation equipment and ask for skilled staff available for possible reintubation.

- Extubate with tracheal tube exchanger in place (tube exchangers are usually well tolerated).

- Delay extubation to allow edema to resolve. If possible, place the patient in a head-up position; consider administering diuretics and dexamethasone before next extubation attempt.

intraoperative cardiac dysrhythmias, such as a history of ventricular arrhythmia, defibrillation pads should be placed in the usual sternal and apical positions prior to positioning. When the patient is turned back to the supine position, there will be a temporary interruption of cardiac compression and possible disconnection of the monitors. The decision to reposition the patient during resuscitation should be based primarily on the effectiveness of external cardiac compressions and defibrillation (or cardioversion) in the prone position. Other considerations include the expected duration of interrupted resuscitation for repositioning, the need for access for other resuscitation procedures (e.g., chest drain insertion, pericardiocentesis, arterial or central venous cannulation), and the condition of the surgical wound (e.g., multiple surgical instruments in situ).

Airway complications

There are many reported complications involving the ETT of patients positioned prone, including kinking, obstruction from secretions, migration towards the carina or mainstem 

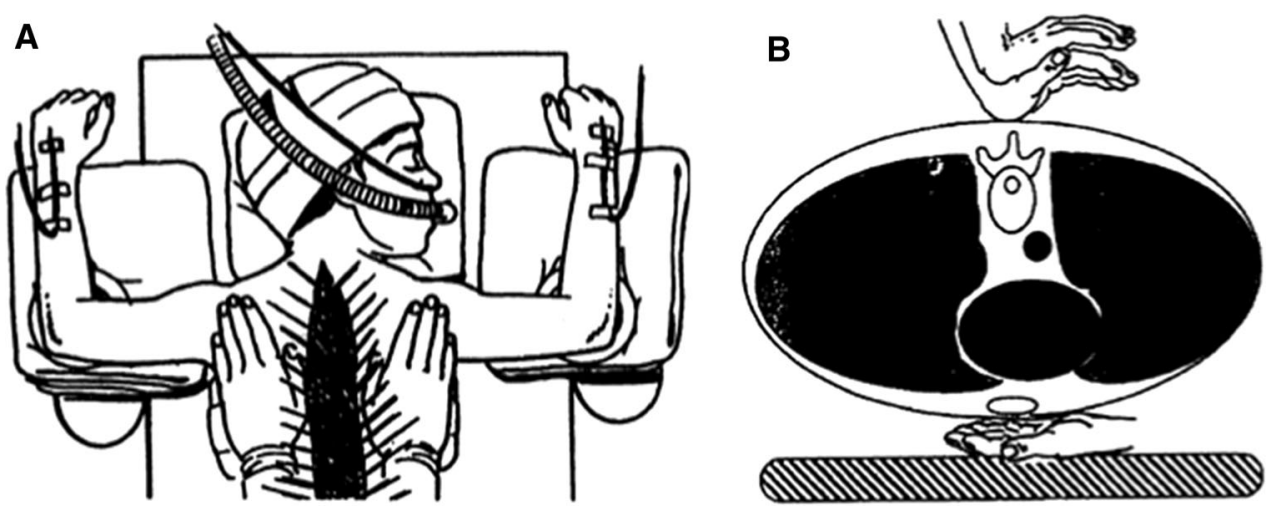

Fig. 1 Methods of cardiac compression when patient is in prone position. (A) Compression lateral to both sides of the spine at the level of scapula in a pediatric patient. (B) Compression over the thoracic spine, with or without counter-pressure, at the lower one-third of the sternum by a second resuscitator. Reproduced with Permission from (A) Tobias JD, Gregory AM, Atwood R, Gurwitz GS. Intraoperative

bronchus, and dislodgement from the patient's trachea. Since kinking can occur during hyperflexion of the neck, a reinforced ETT should be considered over a standard ETT. The drawbacks of the reinforced ETT include an inability to cut the tube, smaller internal diameter, inability to prevent ETT obstruction from teeth biting (if a bite block is not used), and persistent narrowing if deformed (because of lack of recoil). Bite blocks are useful to reduce ETT obstruction caused by teeth and to prevent protrusion of the tongue between the teeth, but hard bite blocks have the potential to cause ulceration of the hard and soft palates as well as tongue edema from venous and lymphatic congestion. Soft gauze blocks placed horizontally between the front upper and lower teeth may reduce the incidence of ETT obstruction from biting and tongue protrusion. ${ }^{33}$

\section{Accidental extubation}

Accidental tracheal extubation with the patient in the prone position can be a catastrophic complication. Even if tracheal intubation was performed easily in the supine position, this represents a challenging airway scenario for several reasons. First, there is less time to re-establish the airway because oxygen reserves may be limited, particularly if the $\mathrm{FiO}_{2}$ has been $<0.6$ ). Second, anesthesiologists are not accustomed to performing bagmask ventilation or attempting airway maneuvres with the patient prone. Third, the head and neck positions may be fixed by head clamps (e.g., during posterior head and spine surgeries), which further limits options to access the airway. If the patient's head is not fixed, it can be turned to access the airway, but bag-mask ventilation may still be difficult because of the acute angle and narrowed airway. The limited mouth opening and neck rotation, as well as an
Cardiopulmonary resuscitation in the prone position. J Paediat Surg 1994;29(12):1537-8. (B) Dequin P-F, Hazouard E, Legras A, Lanotte R, Perrotin D. Cardiopulmonary resuscitation in the prone position: Kouwenhoven revisited. Intensive Care Med 1996;22:1272

Méthodes de massage cardiaque lorsque le patient est en position ventrale

inability to align the oral, oropharyngeal, and laryngeal axes make it almost impossible to re-establish the airway without the use of airway adjuncts and additional expert assistance.

Techniques used to manage this scenario and rescue the airway have been described in published cases of accidental extubation. ${ }^{34}$ A general approach is summarized in Fig. 2. In cases where the ETT has slipped out by only a few centimetres, it may be possible to readvance it through the vocal cords. If the ETT is completely out of the trachea, however, this is a critical emergency and there may be little time before significant hypoxemia occurs. All efforts should be directed to bringing a stretcher into the OR in order to turn the patient immediately from prone to supine onto the stretcher and to secure the airway with the patient in the supine position.

Insertion of a supraglottic device may help to oxygenate the patient while the stretcher and difficult intubation equipment are brought into the OR. A SGA such as a laryngeal mask would appear to be the predominant choice in airway rescue based on reports of its relative ease of insertion in the prone position and high success rates. ${ }^{32}$ However, SGA insertion may be difficult in the obese patient, and successful placement may be hindered by limited lateral rotation of the head and neck in the prone position. In a review of 12 studies in which elective insertion of a SGA was undertaken in patients already in the prone position, the successful insertion rate was 88$100 \%$ for the first attempt and $100 \%$ with second attempt in all studies. ${ }^{13,34}$ Another study comparing the ease of insertion for different types of SGAs in prone patients found that the LMA-Classic ${ }^{\mathrm{TM}}$, LMA-Proseal ${ }^{\mathrm{TM}}$, and LMA-Supreme ${ }^{\mathrm{TM}}$ (LMA North America, San Diego, CA, USA) all performed equally well. ${ }^{35}$ 
Fig. 2 Management algorithm for accidental extubation in prone position. Note: The algorithm may not fit all clinical situations and the management sequence may have to be changed according to patient's condition and clinical setting Algorithme de prise en charge d'une extubation accidentelle en position ventrale

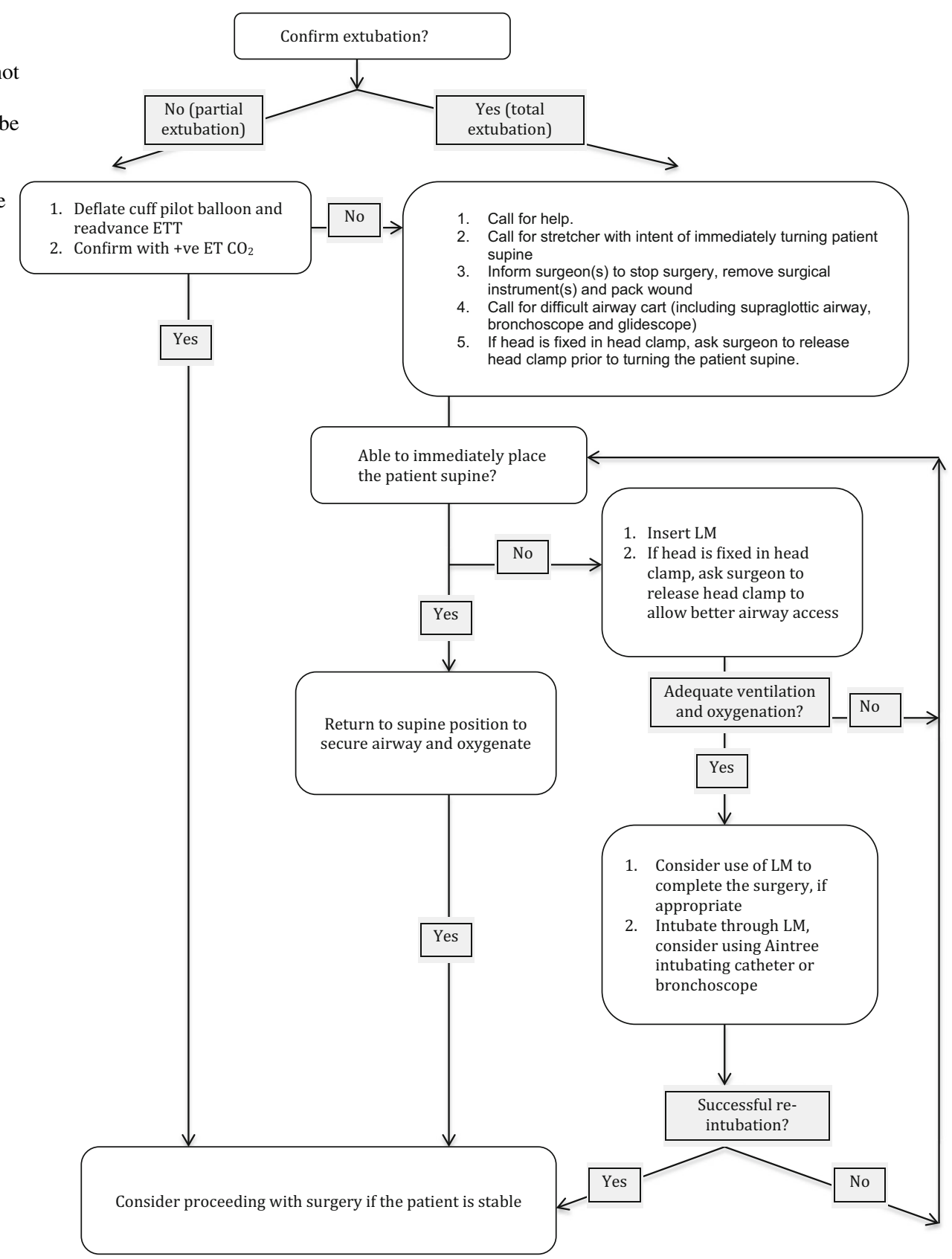

\section{Venous air embolism}

Venous air embolism (VAE) has been reported during spinal surgery in the prone position. Since the surgical site is above the level of the heart, subatmospheric pressures can potentially be generated to entrain air. Fortunately, this complication is uncommon, as most prone positioned patients have slightly elevated venous pressure due to abdominal compression. The true incidence of VAE is unknown but more than 30 cases of VAE have been reported in the literature since the 1960s, with the majority resulting in fatality or severe hemodynamic compromise. Subclinical VAE may be more common than previously thought, as there is no monitoring for VAE in the prone position that is routinely undertaken. ${ }^{1}$ The approach to the diagnosis and management of VAE in the prone patient is similar to that in the supine patient, except that resuscitation is more difficult in the prone patient.

Pressure-related injuries and complications

Pressure-related injuries and complications in the prone position have been widely reported in the medical literature and have involved almost every organ from head to toe. Most of them occur despite best efforts at optimal positioning. Injuries to skin and soft tissue are the most common and 
Table 4 Possible causes of postoperative visual loss (POVL)

\begin{tabular}{|c|c|c|c|}
\hline & Pathophysiology & Presentation & Fundoscopic examination \\
\hline $\begin{array}{l}\text { Anterior } \\
\text { ischemic } \\
\text { optic } \\
\text { neuropathy }\end{array}$ & $\begin{array}{l}\text { - Ischemic injury to the optic nerve (anterior to the lamina } \\
\text { cribrosa) due to occlusion/hypoperfusion of the posterior } \\
\text { ciliary circulation } \\
\text { - Most common cause of POVL following cardiac surgery }\end{array}$ & $\begin{array}{l}\text { - Lucid period of normal } \\
\text { vision (few days) } \\
\text { - Abrupt deterioration of } \\
\text { vision, progressive } \\
\text { over several days } \\
\text { - Typically bilateral } \\
\text { - Ranges from visual field } \\
\text { deficit (inferior) to } \\
\text { complete blindness }\end{array}$ & $\begin{array}{l}\text { - Swollen optic disc } \pm \text { flame-shaped } \\
\text { hemorrhages or splinter hemorrhages } \\
\text { at the optic disc margin } \\
\text { - Optic atrophy 4-6 weeks after the } \\
\text { insult }\end{array}$ \\
\hline $\begin{array}{l}\text { Posterior } \\
\text { ischemic } \\
\text { optic } \\
\text { neuropathy }\end{array}$ & $\begin{array}{l}\text { - Ischemic injury to the optic nerve (posterior to the lamina } \\
\text { cribrosa) due to venous congestion } \\
\text { - Most common cause of POVL following spine surgery }\end{array}$ & $\begin{array}{l}\text { - Presents immediately } \\
\text { after surgery } \\
\text { - Typically bilateral }\end{array}$ & $\begin{array}{l}\text { - Normal fundoscopic examination } \\
\text { - Optic atrophy 4-6 weeks after the } \\
\text { insult }\end{array}$ \\
\hline $\begin{array}{l}\text { Central retinal } \\
\text { artery } \\
\text { occlusion }\end{array}$ & $\begin{array}{l}\text { - Direct sustained compression of the globe } \\
\text { - Associated with periorbital trauma }\end{array}$ & $\begin{array}{l}\text { - Presents immediately } \\
\text { after surgery } \\
\text { - Usually unilateral }\end{array}$ & $\begin{array}{l}\text { - Retinal whitening with attenuated } \\
\text { retinal vessels } \\
\text { - Cherry red spot in the macula } \\
\text { (pathognomonic sign) }\end{array}$ \\
\hline $\begin{array}{l}\text { Cortical } \\
\text { blindness }\end{array}$ & $\begin{array}{l}\text { - Occipital lobe infarct due to } \\
\text { Emboli } \\
\text { Ischemia in watershed area due to significant } \\
\text { intraoperative hypotension }\end{array}$ & $\begin{array}{l}\text { - Present immediately } \\
\text { after surgery } \\
\text { - Typically unilateral }\end{array}$ & - Normal \\
\hline Glaucoma & $\begin{array}{l}\text { - Unknown mechanism } \\
\text { Thought to be due to pupillary blockade by forward } \\
\text { movement of lens against iris during prone positioning } \\
\text { Prone position can further increase already raised } \\
\text { intraocular pressure. It has been used as a provocation } \\
\text { test for acute angle glaucoma }\end{array}$ & $\begin{array}{l}\text { - Intense pain and blurred } \\
\text { vision } \\
\text { - Swollen eyelids, } \\
\text { conjunctiva and } \\
\text { corneal edema. }\end{array}$ & - Normal \\
\hline
\end{tabular}

Table 5 Measures to reduce the incidence of postoperative visual loss

- Consider a staged procedure in anticipation of prolonged surgery, e.g., $>12 \mathrm{hr}$.

- Consider reverse Trendelenburg position (head level higher than heart) and neutral neck position to reduce venous congestion.

- Use invasive arterial blood pressure monitoring.

- Avoid hypotension and hypovolemia. Consider use of colloids to maintain euvolemia, and avoid high-volume crystalloid infusion.

- Avoid anemia (keep hematocrit $>30 \%$ ).

- Routine eye checks every $30 \mathrm{~min}$ to ensure no direct pressure on the eyes.

range from mild skin abrasions and bruises to blistering and necrosis. Other commonly reported pressure-related injuries include those to external organs such as the breasts and external genitalia but can also include visceral organ damage such as acute pancreatitis or acute liver failure. ${ }^{36}$ Unfortunately, the majority of prone position-related complications appear in the literature as case reports or small case series, so the exact incidence of pressure-related injuries and complications is largely unknown. Indeed the sporadic nature of the reported incidents makes one suspect that many more injuries occur but go un-reported.

Peripheral nerve injuries, such as brachial plexus and more distal ulnar nerve palsies, have also been reported following prone positioning. Traditionally, postoperative neuropathy was thought to be caused solely by direct pressure to peripheral nerves. Nowadays, patient comorbidities, surgical factors (e.g., prolonged duration of surgery), and perioperative systemic inflammatory response are all considered to play important roles in the development of perioperative neuropathy. ${ }^{37}$ Intraoperative monitoring of somatosensory evoked potentials (SSEP) may detect nerve compromise. However, there is insufficient evidence to support the routine use of SSEP to detect position-related injuries though one study found that $7 \%$ of patients in the prone position (i.e., "Superman" position) had upper limb SSEP changes, and that the repositioning of affected limb resulted in no postoperative neurologic deficit. ${ }^{38}$ Unfortunately, the symptoms and 
Fig. 3 Prone positioning checklist

Liste de contrôle pour le positionnement ventral

\section{PREPARATION}

\section{Patient:}

Check patient for fixed flexion deformities, prior history of shoulder dislocation or joint surgery, presence of colostomy, ileostomy, pacemakers and breast implants

Secure all lines to prevent dislodgement, and consider saline lock intravenous lines to prevent entanglement.

Increase $\mathrm{FiO} 2$ to 1.0 (until post-position check is completed)

Ensure adequate anesthetic depth.

Obtain baseline neurophysiological monitoring, if needed

\section{Equipment:}

Check table, supports, arm-boards and padding.

Ensure that the equipment is appropriate for patient's age, weight, body habitus, co-morbidities and length and extent of surgery. Consider modifications or alternate positions

$\square$ Consider using reinforced ETT and placement of a soft bite-block when possible.

Check head clamp or foam rest for face

\section{Personnel:}

Have trained and skilled lifters: preferably 6 persons, one each responsible for head, chest (sending and receiving side), pelvis (sending and receiving side), and for legs

\section{CONDUCT}

Disconnect non-essential monitoring just prior to turning the patient

Disconnect the airway from the anesthetic machine. Anesthesiologist counts down for the turn

Maintain head and neck in alignment during turn

Keep stretcher until patient is secured and vitals stable in prone position

\section{POST-POSITIONING CHECK}

\section{Airway}

Reconnect the airway, restore mechanical ventilation and recommence anesthesia.

Ensure no kinking of ETT

Secure breathing circuit, (preferably with two point fixation)

Ensure a disconnection point of circuit for suction, if required

Check that elbow of circuit is upright to prevent secretions clogging the gas analyzer connection signs of nerve injury resulting from positioning may be delayed for as long as three weeks after surgery again leading to under-reporting of injuries. Nevertheless, a simple postoperative assessment of peripheral nerve function might help in the early recognition and management of neuropathies. When a patient is suspected of having a position-related peripheral neuropathy, the initial management should include obtaining a detailed history of the symptoms and performing a full neurological examination. The aim is to identify the location of the injury (e.g., distal nerve vs proximal brachial plexus injury) and to exclude other causes such as stroke. Additional 
Fig. 3 continued

\section{Breathing}

Check $\mathrm{SpO}_{2}$ and $\mathrm{ETCO} 2$

Check spirometry for satisfactory airway pressures and pulmonary compliance.

Auscultate both lungs to rule out endobronchial intubation

Consider reverse Trendenlenburg to reduce face and airway edema, intraocular pressure and to improve respiratory mechanics

\section{Circulation}

Reconnect NIBP, re-zero A-line.

Check cardiac rhythm and hemodynamics.

Re-connect IVs, check patency, ensure accessible ports

\section{Disability}

Head to toe screening for potential complications. See Fig. 4

\section{Exposure}

Ensure quick access to the face if needed

Secure the patient to the OR table (tape or belt across body and legs)

Apply a warming blanket to avoid hypothermia.

Prevent accumulation of skin preparation running down face into airway circuit or running down the sides of the body to accumulate beneath the abdomen

\section{Follow-up}

Document specific positioning actions taken

Check eyes and nose every 30 minutes

Check face and limbs each time OR table is repositioned

Stretcher should be placed outside the OR with a sign "Do not remove stretcher, patient is prone". Ready access to the stretcher is vital should a catastrophic event occur.

* created by authors Drs. Chui, Craen

investigations, such as neuroimaging, nerve conduction, and electromyographic studies may be warranted. We recommend a formal neurology consult for a detailed assessment and follow-up of perioperative neuropathies.

Postoperative visual loss

Postoperative visual loss (POVL) is a rare but devastating complication of prone positioning. ${ }^{39}$ In a nation-wide United States study from1996-2005, the prevalence of POVL was reported as 3.1 per 10,000 patients following spinal surgery in the prone position. ${ }^{40}$ Other large-scale retrospective studies report an incidence ranging from $0.028 \%$ in the Johns Hopkins' database of 14,102 spine cases to $0.2 \%$ in a study involving 3,450 spine cases. ${ }^{41-43}$
Due to the low incidence of POVL, no large prospective observational studies have been reported. The American Society of Anesthesiologists' POVL registry ${ }^{44}$ cites ischemic optic neuropathy (ION) as the most common cause of POVL following spinal surgery ( 83 of 93 cases of POVL). Other causes of POVL, including central retinal artery occlusion, cortical blindness, direct orbital injury, retinal detachment, and acute glaucoma, should be considered in patients with POVL (Table 4). Blood loss greater than $1,000 \mathrm{~mL}$ and duration of anesthesia greater than six hours were identified as strong risk factors for ION. ${ }^{45}$ In a recent case-control study involving 80 patients with ION and 315 matched controls, male sex, obesity, the use of the Wilson frame, and prolonged surgery were found to be independent risk factors for POVL, whereas the use 


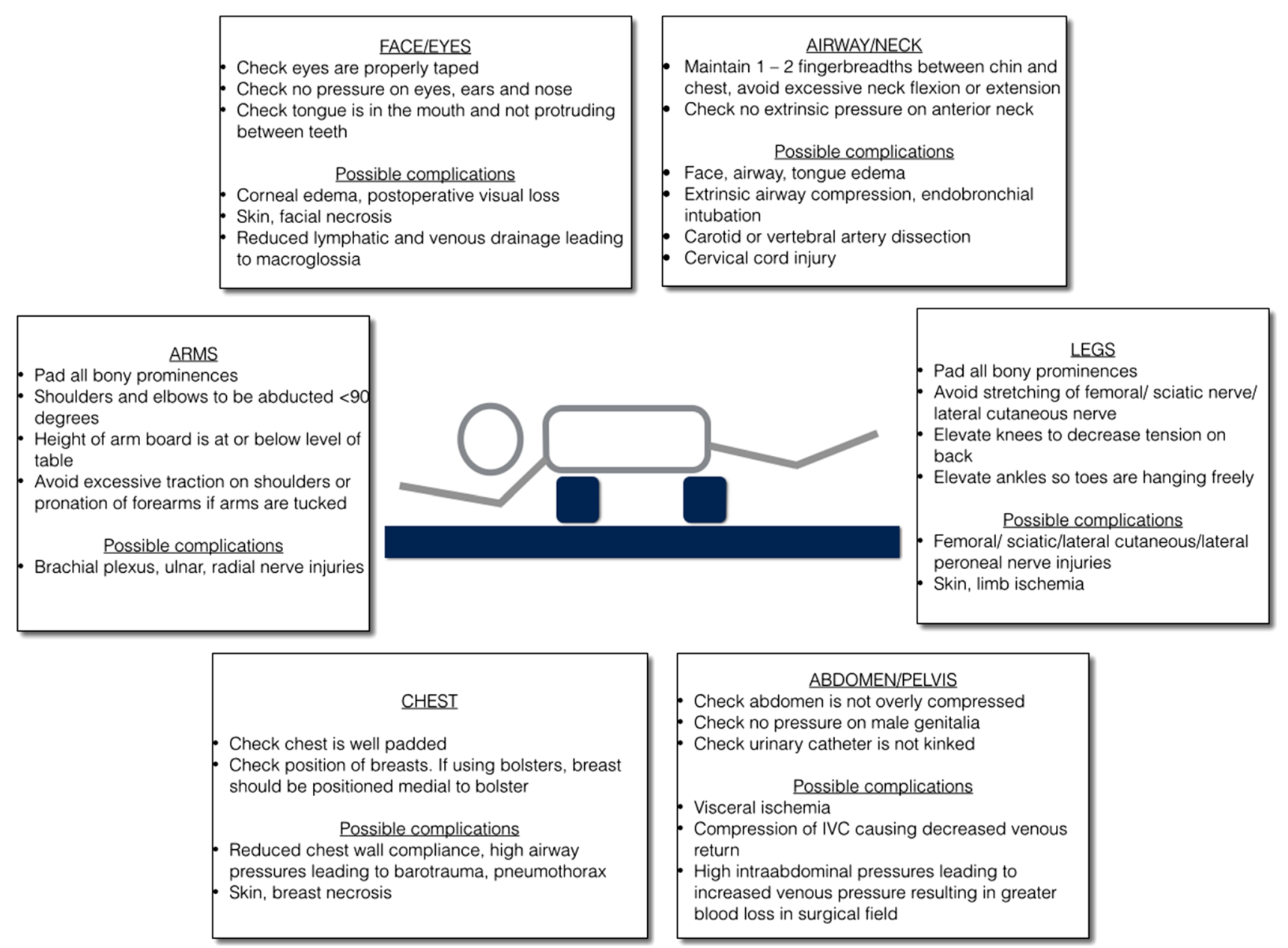

Fig. 4 Head to toe screening in prone positioning

Examen de la tête aux pieds des patients en position ventrale

of colloids was found to be a protective factor. ${ }^{46} \mathrm{~A}$ recent review of the causative factors of POVL provides excellent illustrations and videos. ${ }^{39}$ All episodes of POVL should trigger an urgent referral to an ophthalmologist. General measures to reduce the incidence of POVL (non-specific for prone) are summarized in Table 5.

\section{Strategies to improve patient safety}

General recommendations

Preparation for prone positioning is a labour-intensive task. There are three major steps prior to turning a patient prone (Fig. 3): proper assessment and preparation of the patient, equipment check, and securing the availability of skilled lifters. Equipment used in positioning should be updated and undergo regular safety checks. After positioning a patient prone, a thorough patient check should be performed in a systematic manner to minimize position-related complications (Fig. 4). During surgery, there should be regular checks of the patient's eyes and mouth, and limbs, if possible. The face and limbs should be checked each time the table is repositioned. Careful documentation of positioning during anesthesia is paramount and necessary for medicolegal purposes, and it should include the specific actions taken to minimize injury.

The prone position is commonly used, yet injuries and preventable mishaps continue to be reported. Positioning is often not formally taught to OR staff (surgeons, anesthesiologists, and nurses). Instruction is usually passed down using an apprentice-style "see one, do one" approach. Ideally, positioning should be part of the anesthesia and surgery training as well as part of the OR nursing staff orientation. We recommend a structured team approach and a careful selection of equipment tailored to both the patient and surgery. The systematic use of checklists has also been recommended to help guide OR teams and reduce the rate of prone position-related complications. $^{47}$ 
Disclosure of risks for prone positioning

Given the potential complications and injuries associated with the prone position, it is somewhat surprising that informed patient consent, with full disclosure of the associated risks, is obtained much less often than would be expected. ${ }^{48}$ In the UK, results of a national survey of anesthetists on the informed consent process relating to the prone position showed that only $51 \%$ of respondents reported routinely explaining the risks associated with the prone position to their patients, and only $32 \%$ of those documented the discussed risks. ${ }^{49}$ Respondents discussed both common and rare risks, including facial swelling, redness over pressure areas, peripheral nerve injuries, and POVL.

The responsibility for informed consent and disclosure of the risks associated with prone positioning is usually left to the surgeon at the time of obtaining consent for surgery, and sometimes the discussion of the risks of positioning may be simplified or overlooked. The anesthesiologist can, and should, contribute to the disclosure of risks, especially the potential for postoperative airway edema and prolonged intubation. Supplementary patient information in the form of leaflets and videos may also help to fully informing the patient.

\section{Conclusion}

The safe care of the anesthetized prone patient is guided by a thorough understanding of the physiologic changes that occur in the prone position and the factors that predispose patients to complications from prone positioning. Increasing age, elevated BMI, the presence of comorbidities, and the length of surgery appear to be the most important factors. The OR team should be well prepared, familiar with the equipment being used, meticulous in positioning the patient, and vigilant during surgery to minimize injuries. If the risks are excessive or the patient fails to tolerate the prone position, positioning may need to be modified or alternate positions may need to be adopted. The use of checklists may help anesthesiologists safely conduct the procedure and manage patients in the prone position.

\section{Clinical scenario}

You are asked to provide anesthesia for a 72-yr-old female booked for elective lumbar spine decompression (L2-L5) for spinal stenosis. Her symptoms include bilateral claudication and numbness and paresthesia in the L3-L4 distribution. Her medical history is significant for stable angina, controlled hypertension, and diet-controlled type 2 diabetes. Her past surgical history includes an uneventful rotator cuff repair for recurrent right shoulder dislocation. Her body mass index is $40 \mathrm{~kg} \cdot \mathrm{m}^{-2}$. The neurosurgeon would like the patient positioned prone on a Wilson frame with her head cushioned in a foam headrest and her arms out with the elbows flexed at $90^{\circ}$ on arm boards.

Instructions for completing the continuing professional development (CPD) module

1. Read the current article and the references indicated in bold.

2. Go to: http://www.cas.ca/Members/CPD-Online and select the current module (An update on the prone position).

3. Answer the multiple choice questions regarding the case scenario.

4. Once you have entered all of your answers, you will have access to experts' explanations for all the possible choices.

5. Participants may claim up to four hours of CPD for a total of 12 credits under Section 3 of the CPD program of the Royal College of Physicians and Surgeons of Canada.

\section{La position ventrale: une mise à jour}

\section{Résumé}

ObjectifL'objectif de ce module de développement professionnel continu est de présenter les informations nécessaires à la préparation et la prise en charge clinique d'un patient en position ventrale.

Constatations principales Le positionnement ventral est nécessaire pour les interventions chirurgicales sur la face postérieure d'un patient. Nous avons effectué des recherches dans les bases de données MEDLINE $^{\circledR}$ et EMBASE $^{\mathrm{TM}}$ s'étendant de janvier 2000 à janvier 2015 pour en extraire la littérature portant sur la position ventrale et avons retenu les articles originaux publiés en anglais. Nous avons passé en revue les avantages et les inconvénients de divers équipements utilisés pour le positionnement ventral, les changements physiologiques associés à la position ventrale, et les complications potentielles. Nous avons également passé en revue diverses stratégies pour la réalisation et la prise en charge sécuritaires des complications liées à la position ventrale. 
Conclusion Un âge avancé, un indice de masse corporel élevé, la présence de comorbidités et une durée de chirurgie prolongée semblent constituer les facteurs de risque les plus importants de complications associées au positionnement ventral. Nous recommandons une approche d'équipe structurée et une sélection minutieuse d'équipement en fonction du patient et de la chirurgie. L'utilisation méthodique de listes de contrôle (checklists) est recommandée afin de guider les équipes de salle d'opération et de réduire les complications liées à la position ventrale. Les anesthésiologistes doivent être prêts à faire face à des urgences peropératoires majeures (par ex. une extubation accidentelle) et à anticiper les complications postopératoires (par ex., un œedème des voies aériennes ou une perte de la vision).

\section{Objectifs}

Après avoir lu ce module, l'anesthésiologiste devrait être en mesure de:

1. Identifier les divers types d'équipement utilisés lors du positionnement ventral, notamment leurs indications, leurs avantages et leurs inconvénients.

2. Décrire les changements physiologiques associés à la position ventrale, particulièrement ses effets sur le système cardiorespiratoire.

3. Comprendre les complications potentielles qui peuvent survenir lors du positionnement ventral et décrire les techniques utilisées pour les prévenir et les prendre en charge.

4. Formuler une stratégie pour l'extubation planifiée après une chirurgie prolongée en position ventrale.

5. Décrire la prise en charge d'une extubation accidentelle pendant la chirurgie en position ventrale.

6. Discuter de stratégies pour améliorer la sécurité des patients subissant une chirurgie en position ventrale.

Depuis les années 1930, la position ventrale est utilisée afin d'offrir un accès chirurgical postérieur pour un vaste éventail d'interventions. Parmi les interventions chirurgicales fréquemment pratiquées en position ventrale, citons la neurochirurgie (par ex., de la fosse postérieure ou de la colonne postérieure), les interventions urologiques (par ex., les néphrostomies et lithotrities), la chirurgie générale (particulièrement anorectale), la plastie (par ex. le débridement d'ulcères sacrés) et les interventions orthopédiques (par ex. une réparation du tendon d'Achille). Divers équipements sont utilisés pour le positionnement du patient, notamment des tables, des supports, des appuie-bras, des appuie-têtes, et des clameaux crâniens (tableaux 1,2). Dans la plupart des cas, le choix des équipements se fait principalement selon les préférences des chirurgiens. Toutefois, en raison de la nature de plus en plus complexe des chirurgies ainsi que $\mathrm{du}$ vieillissement et de l'embonpoint toujours plus prononcé des patients, des modifications ont été apportées aux équipements au fil du temps afin de tenter de réduire les complications et les blessures des patients. La littérature médicale publiée s'est principalement concentrée sur les effets physiologiques et les complications associés à la position ventrale. Dans ce module de développement professionnel continu, nous passerons en revue les effets physiologiques associés au retournement d'un patient sur le ventre ainsi que les avantages et inconvénients des diverses sortes d'équipement utilisées dans le positionnement ventral. Nous passerons également en revue plusieurs stratégies pour la réalisation et la prise en charge sécuritaires des complications liées à cette position.

\section{Les changements physiologiques associés à la position ventrale}

Effets sur le système respiratoire

Chez l'humain, la distribution de la ventilation et de la perfusion est principalement régie par l'architecture broncho-alvéolaire intrinsèque et, dans une moindre mesure, par les effets de la pesanteur sur la ventilation $(\mathrm{V})$ et le flux sanguin $(\mathrm{Q}){ }^{1}{ }^{1}$ Lorsqu'un patient sain sous anesthésie est allongé sur le dos, la perfusion se diffuse plutôt aux alvéoles dorsales (postérieures) en raison d'une résistance vasculaire pulmonaire intrinsèque inférieure, alors que la ventilation se distribue plutôt aux alvéoles moyennes à dorsales en raison des caractéristiques structurelles des voies aériennes. ${ }^{2}$ Lorsqu'on retourne un patient sur le ventre, la pesanteur contrecarre partiellement la résistance vasculaire pulmonaire accrue dans les alvéoles ventrales (antérieures) et renverse partiellement la distribution de la perfusion. Par conséquent, la perfusion est distribuée de façon plus uniforme (ou égale) des zones dorsales à ventrales en position ventrale, alors que la distribution de la ventilation demeure en grande partie inchangée par les forces gravitationnelles. Globalement, le décalage V/Q est réduit, d'où une meilleure oxygénation artérielle. Toutefois, si une pression expiratoire positive (PEEP) de plus de $10 \mathrm{~cm} \mathrm{H}_{2} \mathrm{O}$ est appliquée, le flux sanguin se redistribue des zones dorsales à ventrales, ce qui augmente le décalage V/Q et provoque une réduction paradoxale de l'oxygénation artérielle. ${ }^{3}$ La plupart du temps, chez un patient sain sous anesthésie en position ventrale, la réduction de l'oxygénation artérielle n'a aucune incidence clinique; par conséquent, le recours 
Tableau 1 Matériel fréquemment utilisé en position ventrale

\begin{tabular}{|c|c|c|c|}
\hline Type & Description & Avantages & Inconvénients \\
\hline & $\begin{array}{l}\text { - Coussinets de gel } \\
\text { ajustables latéralement afin de } \\
\text { réduire la compression thoracique } \\
\text { - Comporte un mécanisme à } \\
\text { manivelle afin de réduire la } \\
\text { lordose lombaire }\end{array}$ & $\begin{array}{l}\text { - Prétend réduire le saignement } \\
\text { chirurgical et améliorer l'accès } \\
\text { chirurgical, particulièrement lors } \\
\text { les interventions d'arthrodèse } \\
\text { lombaire transforaminale }\end{array}$ & $\begin{array}{l}\text { - Augmentation de la baisse } \\
\text { d'acuité visuelle après } \\
\text { chirurgie (? en raison de la } \\
\text { position tête en bas) } \\
\text { - Compression abdominale } \\
\text { partielle } \\
\text { - Pression accrue sur les seins } \\
\text { volumineux ou pendants }\end{array}$ \\
\hline
\end{tabular}

Pont de Wilson

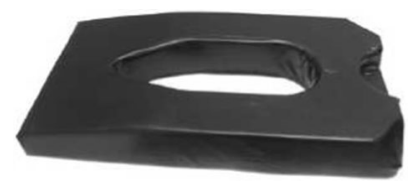

Matelas/Pont de Montréal

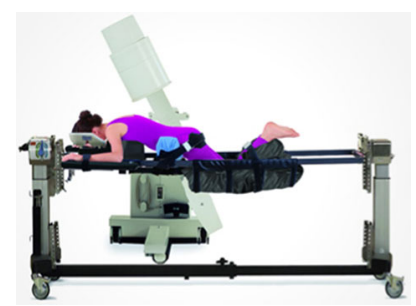

Table de Jackson

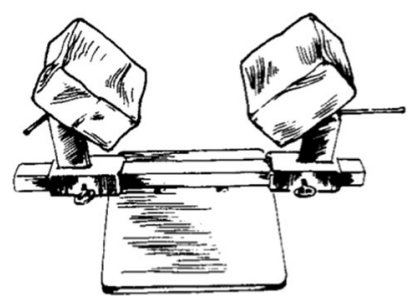

Support de Relton et Hall

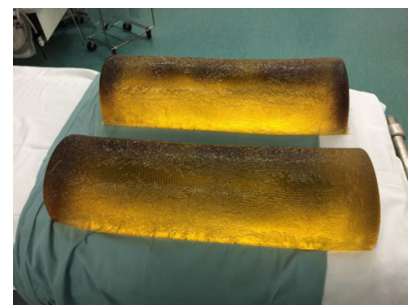

- Quatre supports individuellement ajustables en deux paires en forme de V s'inclinant vers l'intérieur pour soutenir la cage thoracique latérale et le bassin antérolatéral

Fabriqué en plastique et mousse de caoutchouc

- Généralement rembourré à l'aide de coussinets de gel supplémentaires afin d'éviter les lésions liées à la pression

- La cavité centrale permet une décompression abdominale

- Supports thoraciques et abdominaux ajustables

- Les bras peuvent être tendus à $90^{\circ}$ ou bordés le long du corps

- Jambes au niveau du cœur ou plus basses
- Compression abdominale et thoracique acceptable pour les patients non obèses
- Compression abdominale chez les patients obèses

- On a rapporté des lésions liées à la pression chez un patient petit et obèse au niveau des protubérances osseuses

- La table peut être tournée à $180^{\circ}$ • Coût sur son axe

- L'abdomen peut pendre librement
- Réduit la pression intraabdominale

- Tend à corriger la scoliose

- Ajustable pour toutes les morphologies et degrés de scoliose

- Très stable

- Peut être modifié pour permettre une traction squelettique

Traversins en gel / mousse

Les traversins peuvent être fabriqués • Bon marché en gel, mousse roulée ou à l'aide de couvertures
- Facilement disponibles

- La taille peut être ajustée en fonction de la morphologie du patient
- Augmente la lordose lombaire (ne convient pas à la chirurgie discale)
- Compression partielle de la poitrine et de l'abdomen 
Tableau 1 continued

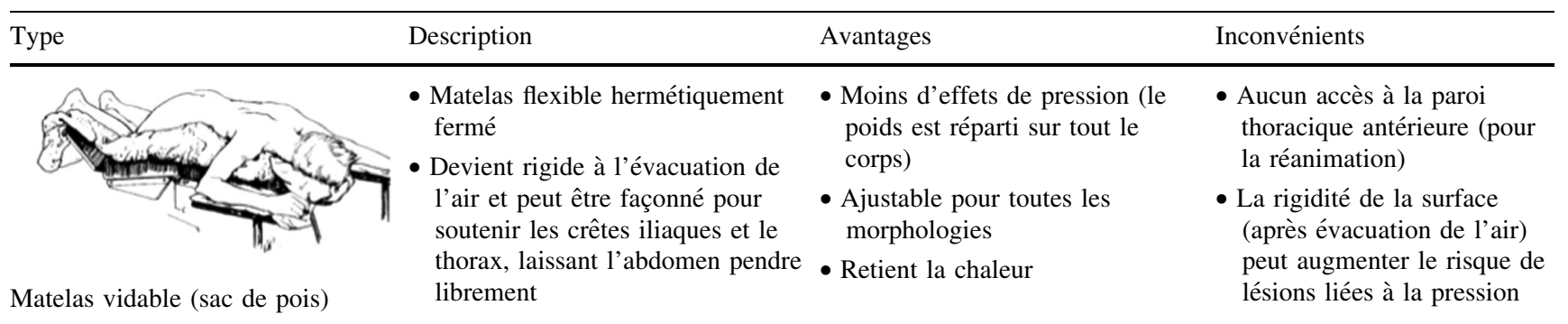

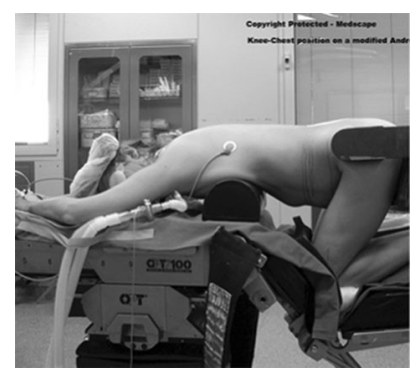

- L'inclinaison de la tête vers le haut rend le dos horizontal

- La poitrine est rembourrée

- La tête est tournée, les bras tendus au-dessus de la tête
- Décompression abdominale excellente, réduit l'engorgement veineux

- Le poids est porté par les tubérosités ischiatiques (pas les genoux)

- Réduit le risque de lésion d'écrasement aux jambes et de thrombose veineuse profonde
- Position laborieuse à réaliser et instable

- La ventilation est bonne mais le débit cardiaque chute de façon significative

- Risque de syndrome des loges des muscles fessiers et des jambes en raison d'une flexion excessive des hanches/genoux

Dispositif génupectoral (pour position génupectorale)

Modifié et reproduit avec la permission de: Edgcombe H, Carter K, Yarrow S. Anaesthesia in the prone position. Br J Anaesth 2008; 100: 165-83 Les images du pont Relton-Hall et du matelas vidable sont reproduites avec la permission de: Wadsworth R, Anderton JM, Vohra A. The effect of four different surgical prone positions on cardiovascular parameters in healthy volunteers. Anaesthesia 1996; 51: 819-22

L'illustration du dispositif génupectoral est reproduite avec la permission de: Rigamonti A, Gemma M, Rocca A, Messina M, Bignami E, Beretta $L$. Prone versus knee-chest position for microdiscectomy: a prospective randomized study of intra-abdominal pressure and intraoperative bleeding. Spine (Phila Pa 1976) 2005; 30: 1918-23

systématique à une PEEP n'est donc pas nécessaire ni recommandé pour la majorité des patients anesthésiés en position ventrale.

En revanche, chez les patients atteints d'un syndrome de détresse respiratoire aigu (SDRA) grave, le positionnement ventral provoque le recrutement des alvéoles dorsales (postérieures) et le dérecrutement des alvéoles ventrales (antérieures), sans altération significative de la perfusion sous des conditions de PEEP basse. ${ }^{4}$ L'ajout d'une PEEP plus élevée $\left(>10 \mathrm{~cm} \mathrm{H}_{2} \mathrm{O}\right.$ ) entraîne une redistribution du flux sanguin qui correspond à la redistribution de la ventilation, ce qui provoque alors une oxygénation encore plus élevée. ${ }^{4}$ C'est pour cette raison que le positionnement ventral est utilisé pour améliorer l'oxygénation de patients souffrant de SDRA grave; en outre, il a été démontré que cette position améliorait la survie dans un contexte de soins critiques (risque relatif de réduction des décès, $16 \%$ ). ${ }^{5}$

Chez le patient sain anesthésié en position ventrale, les modifications de la mécanique pulmonaire sont minimes. Bien que des études aient rapporté que la résistance totale du système respiratoire augmentait de $20 \%$, la résistance des voies aériennes ne change pas en position ventrale. ${ }^{1,6}$ Fait intéressant, la réduction de la capacité résiduelle fonctionnelle observée chez les patients anesthésiés en position ventrale est moins importante que celle observée chez les patients anesthésiés en décubitus dorsal (-12\% vs $-44 \%$, respectivement). ${ }^{1}$ Il convient toutefois de souligner que ces résultats, rapportant une mécanique pulmonaire en grande partie inchangée, ont été observés lors d'un positionnement ventral méticuleux et optimal dans le cadre des études originales.

Effets sur le système cardiovasculaire

Les effets physiologiques cardiovasculaires du positionnement ventral sont documentés depuis le début des années 1990. Les premières études utilisant des sondes artérielles pulmonaires, tout comme d'autres études plus récentes ayant recours à l'échocardiographie transœsophagienne (ETO), montrent toutes une réduction de $10-20 \%$ de l'index cardiaque (IC) chez les patients sains anesthésiés en position ventrale. ${ }^{7}$ Les causes de cette réduction comprennent une précharge réduite en raison de la compression de la veine cave inférieure et/ou une réduction de la compliance ventriculaire gauche (VG) en raison de l'augmentation de la pression intrathoracique. La résistance 


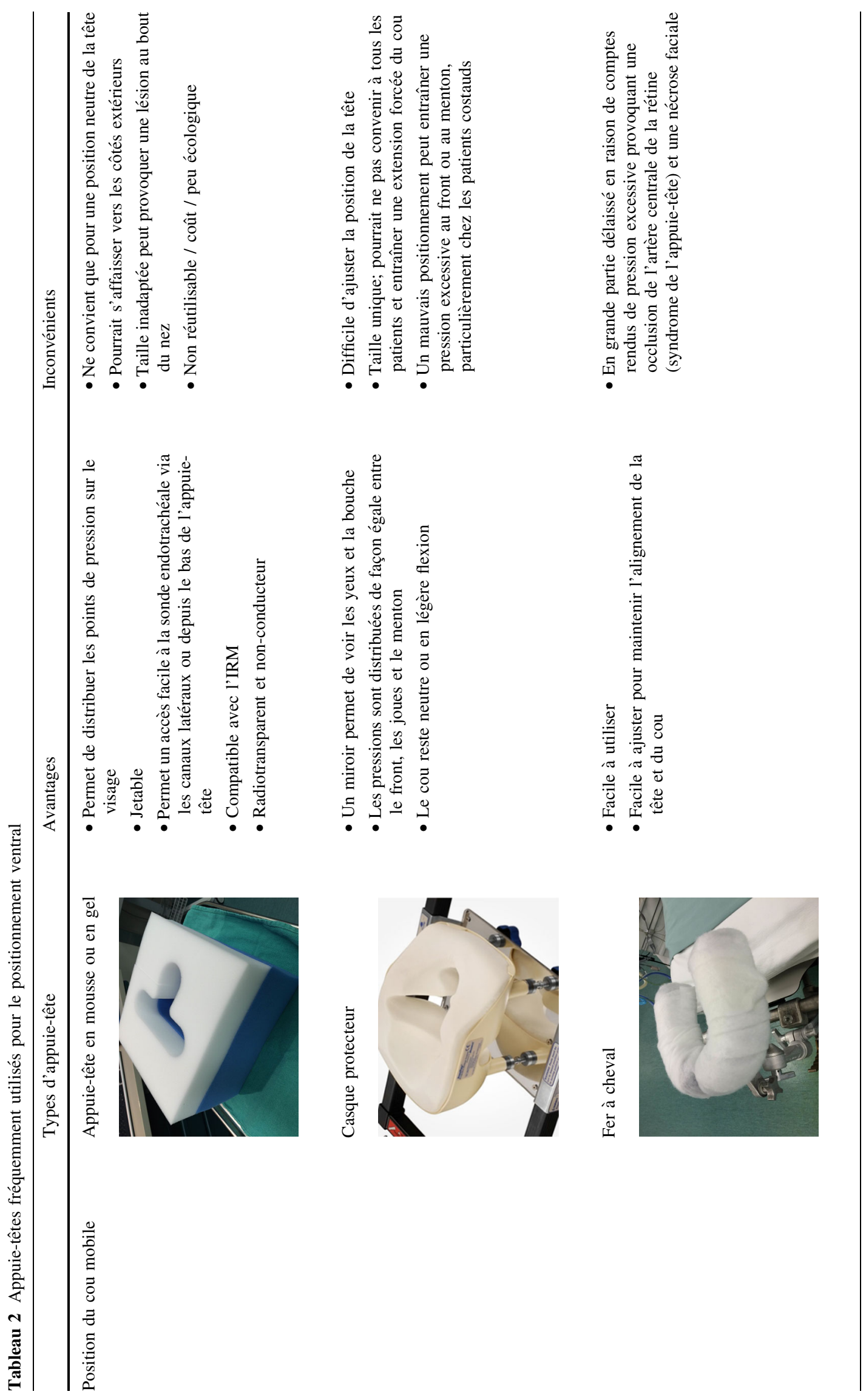




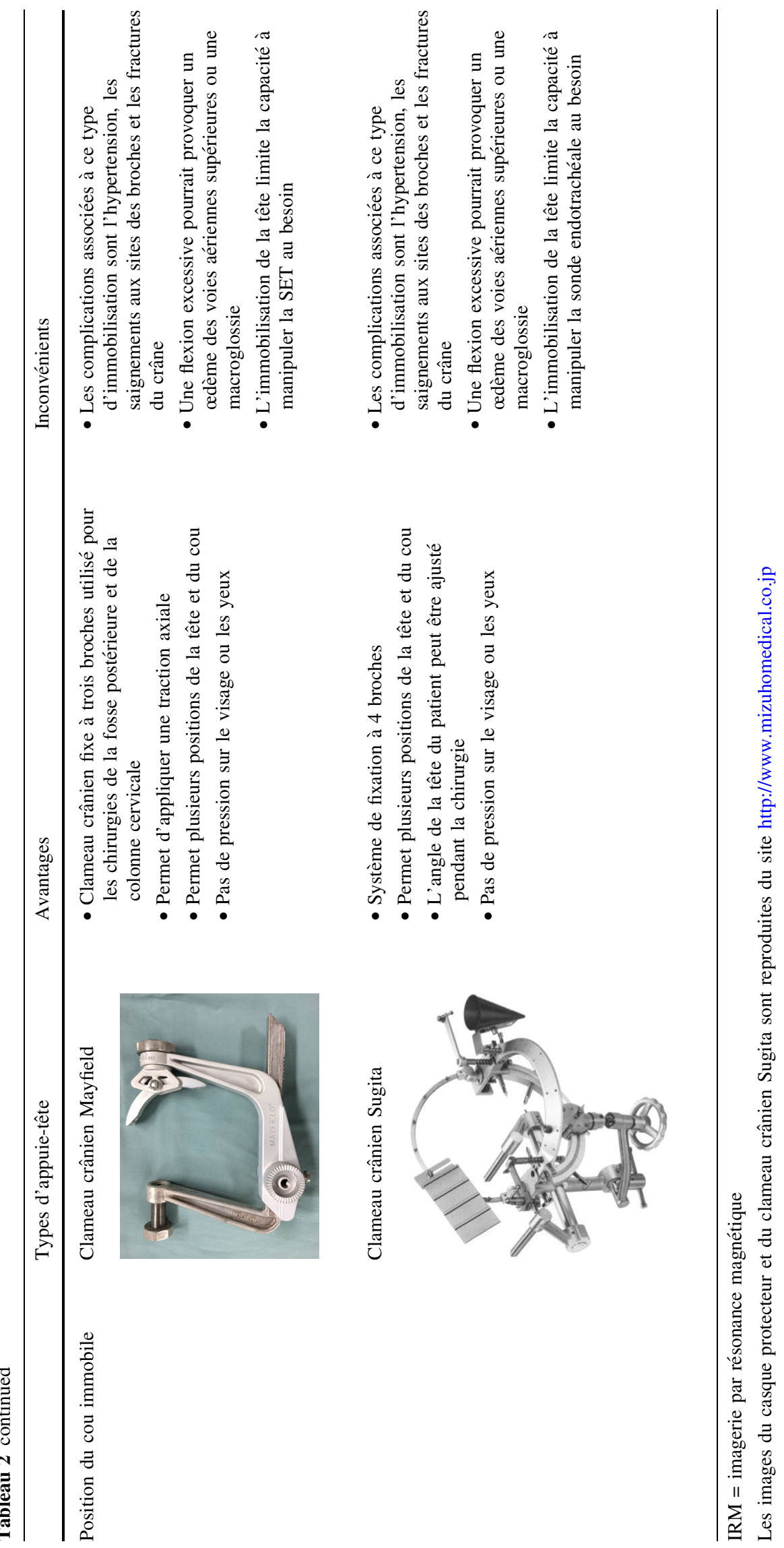


vasculaire systémique demeure quasi inchangée. Dans une étude d'ETO chez des patients sains subissant une laminectomie lombaire, les auteurs ont confirmé une réduction significative de l'aire télédiastolique du VG et une atténuation du pic systolique du flux veineux pulmonaire, reflétant une réduction aiguë des pressions de remplissage du VG. ${ }^{7}$ Chez des patients sains, ces changements sont largement compensés par des augmentations de la contractilité cardiaque et de la fraction d'éjection VG. Globalement, malgré la légère réduction de l'IC, la pression sanguine systolique et la fréquence cardiaque demeurent stables. ${ }^{8}$ Il est important de souligner que ces changements cardiovasculaires mineurs ont été observés chez des patients sains qui avaient été positionnés de façon méticuleuse sur le ventre, ce qui signifie qu'aucun coussin n'entravait les principaux vaisseaux ou le retour veineux. On peut prévoir des changements hémodynamiques plus importants si les patients présentent un indice de masse corporel (IMC) élevé, des comorbidités cardiaques ou respiratoires, et/ou s'ils sont positionnés de façon sous-optimale. Dans une étude utilisant la tomographie d'émission monophotonique (SPECT scan), les auteurs se sont intéressés aux effets du positionnement ventral sur la fonction cardiaque chez des patients éveillés possédant des antécédents d'infarctus du myocarde ou de cardiopathie ischémique. 9 Ces auteurs ont observé une réduction significative de l'IC et de la fraction d'éjection VG chez tous les patients. Les réductions de l'IC étaient plus prononcées chez les patients ayant au préalable souffert de dysfonction systolique. 9

Les patients présentant une mauvaise fonction cardiaque ou des problèmes cardiaques complexes et nécessitant une chirurgie en position ventrale sont assez nombreux. On a rapporté dans la littérature des cas de chirurgies non urgentes en position ventrale réalisées chez des patients souffrant de sténose aortique grave ${ }^{10}$ ou ayant un dispositif d'assistance VG. ${ }^{11}$ Étant donné la diversité des cardiopathies qui s'accompagnent de fonction systolique et diastolique entravée, il est difficile de prévoir les conséquences hémodynamiques d'un retournement en position ventrale pendant l'anesthésie chez de tels patients. En règle générale, tous les patients dépendants d'une précharge, ou présentant une réserve contractile cardiaque faible, ou une dysfonction diastolique préexistante, courent le risque de complications hémodynamiques pendant le positionnement ventral. Ces patients devraient être évalués avec soin avant l'opération et on devrait envisager un éventuel monitorage invasif pendant l'opération.

\section{La prise en charge anesthésique pendant le positionnement ventral}

Cette section aborde la préparation et la prise en charge des patients subissant des interventions en position ventrale.
On propose l'approche suivante dans de tels cas: déterminer si le patient est un bon candidat ou non pour un positionnement ventral; préparer l'équipement (y compris la table et les appuie-têtes); anticiper les complications hémodynamiques et ventilatoires potentielles; et suivre une liste de contrôle (checklist) pour le positionnement et l'extubation sécuritaire afin de minimiser les risques de complications.

\section{Évaluation préopératoire}

L'évaluation préopératoire a pour objectif d'identifier les patients présentant des comorbidités associées aux complications liées à la position ventrale. Voici quelques-uns des facteurs de risque liés au patient: mobilité réduite au niveau du cou, lésion cardiaque obstructive (telle que la sténose aortique), hypertension pulmonaire, maladie pulmonaire obstructive (MPOC) et obésité morbide avec un pannus abdominal conséquent. Une revue minutieuse des antécédents du patient et un examen physique approfondi devraient rendre compte de l'existence et de la gravité de telles conditions. De plus, il faut porter une attention particulière à la mobilité du cou et des articulations (particulièrement au niveau des épaules, des coudes et des hanches) et à la présence d'une cyphose importante. La présence de symptômes reliés aux mouvements des bras ou du cou, tels ceux observés lors de sténose de la colonne cervicale ou d'un syndrome de la traversée thoracobrachiale, doit faire l'objet d'un examen approfondi. Les patients qui seront positionnés avec les bras tendus au-dessus de la tête doivent être capables de prendre confortablement cette « position de capitulation / position de Superman » avant l'opération. Si un patient ne peut le faire en raison d'une paresthésie, d'un engourdissement ou de mobilité restreinte, il faut envisager la possibilité de de placer les bras le long du corps durant la chirurgie. Enfin, la présence d'implants mammaires, de stimulateurs cardiaques ou de sacs de stomie doit être notée: ces dispositifs pourraient nécessiter une attention particulière et un rembourrage supplémentaire. S'il persiste une inquiétude quant au positionnement ventral, il convient d'évaluer la faisabilité de l'intervention dans une autre position et d'en discuter avec le chirurgien avant de procéder au positionnement du patient.

\section{Induction / prise en charge des voies aériennes}

La stratégie de prise en charge des voies aériennes la plus fréquemment utilisée chez les patients nécessitant un positionnement ventral consiste à pratiquer d'abord une intubation trachéale avec le patient en décubitus dorsal, puis de le tourner en position ventrale. Certains ont suggéré de placer un patient éveillé en position ventrale avant l'induction de l'anesthésie générale de façon à réduire les 
blessures aux voies aériennes et liées à la pression. Dans une étude randomisée contrôlée publiée récemment qui comparait l'induction en décubitus dorsal (avec intubation endotrachéale) à une induction en position ventrale (avec insertion d'un dispositif supraglottique), le seul avantage observé était une réduction significative, d'un point de vue statistique mais non clinique, du temps jusqu'à ce que le patient soit prêt pour le début de la chirurgie ( 25 min vs 30 min, respectivement; $P<0,001) .{ }^{12}$ La perte potentielle des voies aériennes, les choix limités en matière de dispositifs et de manœuvres de prise en charge des voies aériennes, ainsi que les complications hémodynamiques potentielles, sont les points majeurs de dissuasion quand il s'agit d'induire une anesthésie générale en position ventrale. ${ }^{13}$ Par contre, les patients dont la colonne vertébrale est instable courent le risque d'une lésion neurologique supplémentaire s'ils sont inconscients pendant le retournement en position ventrale. L'approche à privilégier chez de tels patients pourrait consister à sécuriser les voies aériennes du patient alors qu'il est éveillé et en décubitus dorsal, puis de le positionner sur le ventre et de répéter l'examen neurologique avant l'induction de l'anesthésie. ${ }^{14,15}$

\section{Stratégie de ventilation}

Si des patients sains sont correctement positionnés sur le ventre, les changements au niveau de la mécanique pulmonaire et des échanges gazeux devraient être minimes. Toutefois, une mauvaise compliance de la cage thoracique et des pressions élevées au niveau des voies aériennes sont fréquemment observées chez les patients mal positionnés - ce qui souligne l'importance de la spirométrie peropératoire. Les effets négatifs du positionnement ventral sur la mécanique pulmonaire peuvent être plus prononcés chez les patients souffrant de maladie pulmonaire préexistante, de tolérance réduite à l'exercice, ou encore d'obésité morbide, mais l'ampleur de ces changements peut être mitigée avec un bon positionnement. ${ }^{16}$

Dans une étude comparant la ventilation en pression contrôlée à la ventilation en volume contrôlé chez des patients subissant une chirurgie de la colonne lombaire, on a observé des pressions maximales des voies aériennes plus basses avec la ventilation en pression contrôlée tout en obtenant une ventilation minute et des taux de dioxyde de carbone télé-expiratoire semblables. ${ }^{17}$ Toutefois, l'étude n'a pas trouvé de différence dans l'incidence de lésion pulmonaire aiguë ou de barotraumatisme entre les deux modes de ventilation.
Prise en charge hémodynamique

Un positionnement méticuleux afin de réduire la pression thoracique et abdominale est essentiel si l'on souhaite minimiser les changements hémodynamiques néfastes en position ventrale. Dans la pratique clinique, la plupart des patients sains tolèrent bien la position ventrale, ce qui donne l'impression erronée que le positionnement ventral n'est pas associé à d'importants changements hémodynamiques. Toutefois, l'impact hémodynamique est plus prononcé chez les patients souffrant d'une pression thoracique et abdominale accrue, d'obésité du tronc, ou lorsque le positionnement ventral est modifié afin d'améliorer l'accès chirurgical (par ex. une flexion lombaire exagérée sur un pont de Wilson (Wilson frame) ou en position génupectorale). ${ }^{18} \mathrm{La}$ position de Trendelenburg inversée est également associée à des complications hémodynamiques en raison de l'accumulation de sang dans les membres inférieurs.

Outre l'application d'un monitorage standard des patients, ${ }^{19}$ un monitorage invasif de la pression artérielle devrait être mis en place chez les patients présentant des problèmes cardiorespiratoires, une obésité morbide, ainsi que lors d'opérations prolongées ou d'interventions où des pertes sanguines importantes sont anticipées. Un monitorage non invasif du débit cardiaque ou une ETO pourraient également s'avérer utiles chez certains patients. Les dispositifs de monitorage non invasif du débit cardiaque qui se fondent sur le débit systolique ou sur la variation de la pression différentielle ont été validés pour prédire la réponse au remplissage en position ventrale. ${ }^{20}$ Quant à l'ETO en position ventrale, son utilité est diminuée par les mouvements restreints de la sonde et les fenêtres échocardiographiques limitées, ainsi que par des inquiétudes reliées au risque de lésions de la langue et du pharynx lors d'interventions prolongées. Il pourrait être extrêmement difficile d'insérer une sonde d'ETO après le positionnement $\mathrm{du}$ patient en position ventrale, particulièrement si sa tête est maintenue dans un clameau crânien Mayfield. L'usage de l'ETO est donc généralement réservé à l'évaluation des complications hémodynamiques peropératoires inexpliquées.

Lorsque le patient est en position ventrale, les objectifs hémodynamiques sont de maintenir un rythme sinusal et des fréquences cardiaques normales (bien que dans les limites supérieures de la normale), de garantir une précharge adéquate du VG et de maintenir la contractilité cardiaque. Il a été démontré qu'une précharge volumique de routine des patients réduisait les effets hypotenseurs de la position ventrale. ${ }^{21}$ Chez certains patients, des agents inotropes pourraient être indiqués pour maintenir l'IC et les 
pressions de perfusion coronaire et cérébrale. Si le patient devient hémodynamiquement instable après avoir été positionné sur le ventre, le brancard sur lequel il a été induit devrait rester dans la salle d'opération (SO) jusqu'à ce que ses signes vitaux soient stabilisés afin de pouvoir le repositionner provisoirement sur le dos dans les plus brefs délais, au besoin.

Peu d'études se sont intéressées au choix d'agents anesthésiques pour les interventions réalisées en position ventrale. Dans l'une de ces études, les effets hémodynamiques du propofol et ceux de l'isoflurane chez des patients sains en position ventrale ont été comparés. L'étude a montré que l'anesthésie au propofol était associée à une réduction plus importante de l'IC $(0,7$ $\mathrm{L} \cdot \mathrm{min}^{-1} \cdot \mathrm{m}^{-2}$ vs $0,4 \mathrm{~L} \cdot \mathrm{min}^{-1} \cdot \mathrm{m}^{-2}$, respectivement; $P=$ 0,001). ${ }^{22}$ Il n'existe pas non plus beaucoup d'études comparant différents agents anesthésiques chez des patients souffrant de cardiopathies préexistantes et subissant une chirurgie en position ventrale.

Extubation après une chirurgie en position ventrale

Quelques comptes rendus dans la littérature rapportent des complications au niveau des voies aériennes et des quasi-accidents après une extubation trachéale planifiée chez des patients en position ventrale. ${ }^{23-26}$ Les raisons rapportées pour expliquer l'obstruction des voies aériennes et l'échec des tentatives de rétablissement des voies aériennes incluent une macroglossie, un œdème supraglottique/laryngé, un traumatisme chirurgical direct aux tissus mous paratrachéaux (pendant des chirurgies de la colonne cervicale postérieure), et une traction / un traumatisme aux canaux salivaires (entraînant une enflure au niveau du pharynx). L'œdème des voies aériennes supérieures et la macroglossie peuvent être causées par une compression locale directe, une obstruction veineuse ou lymphatique (à cause de la rotation du cou ou de son hyperflexion), et/ou une hypoperfusion tissulaire due à une hypotension systémique. De plus, les tissus odématiés saignent facilement pendant les tentatives de rétablissement des voies aériennes. Enfin, la toux et les laryngospasmes peuvent également mettre en péril les voies aériennes supérieures.

Une chirurgie prolongée et des transferts liquidiens importants sont associés à un œdème des voies aériennes supérieures plus grave. Il n'existe que peu d'études comparant l'effet des colloïdes à celui des cristalloïdes sur la gravité de l'œdème des voies aériennes. Lorsque cela est possible, une position de Trendelenburg inversée en position ventrale pourrait réduire l'œdème du visage et des voies aériennes ainsi que la pression intraoculaire tout en améliorant la mécanique respiratoire.
Des directives ont été publiées concernant les mesures de sécurité à prendre lorsqu'on effectue une extubation trachéale, ainsi que sur la gestion des échecs d'extubation. ${ }^{26,27}$ La décision de retarder l'extubation devrait se fonder sur une évaluation de risque personnalisée qui tiendra compte des facteurs liés au patient et à la chirurgie. Les résultats d'une étude rétrospective portant sur des craniotomies postérieures ont montré qu'un statut physique ASA (American Society of Anesthesiologists) plus élevé, une durée prolongée de chirurgie, des pertes sanguines plus importantes et des volumes importants de cristalloïdes étaient tous des facteurs associés à la décision de retarder l'extubation. ${ }^{28}$ Si l'on souhaite une extubation précoce, l'anesthésiologiste doit déterminer avec soin la probabilité de réussite de l'extubation, et avoir un plan pour l'extubation et la ré-intubation, le cas échéant (tableau 3). Il convient de mentionner que l'œdème des voies aériennes supérieures (ou l'obstruction) peut apparaître jusqu'à $12 \mathrm{~h}$ après l'extubation, d'où la nécessité de monitorer ces patients attentivement après l'extubation.

\section{Complications possibles et leur prise en charge}

Les complications liées au changement de position

La rotation d'un patient sur le ventre s'accompagne souvent d'une interruption temporaire de monitorage du patient, et peut être associée au délogement de la sonde endotrachéale (SET) ou de sondes intraveineuses ou artérielles. Une désaturation en oxygène peut aussi survenir pendant la période non ventilée qui s'ensuit. En maintenant les patients à $100 \%$ d' $\mathrm{O}_{2}$ avant le changement de position, on peut mitiger ce problème en maximisant les réserves d'oxygène. La déconnexion temporaire du circuit respiratoire interrompt également la diffusion des anesthésiques par inhalation, ce qui peut augmenter le risque de regain de conscience des patients. De plus, des blessures physiques au patient et au personnel peuvent survenir pendant le positionnement. Il est important d'offrir une formation adaptée et spécifique à tous les membres de l'équipe de $\mathrm{SO}$ afin de réduire ces risques.

La réanimation en position ventrale

Plusieurs comptes rendus décrivent des cas de réanimation réussie de patients en position ventrale. L'approche pour réanimer les patients en position ventrale est très similaire à celle adoptée en décubitus dorsal. Bien que les directives générales et les algorithmes de soins immédiats et de réanimation d'urgence soient les mêmes, il existe quelques 
Tableau 3 Stratégies pour une extubation sécuritaire après une chirurgie en position ventrale

Questions à poser avant l'extubation trachéale

Facteurs chirurgicaux

- La chirurgie a-t-elle duré $>$ de 12 h?

- Y a-t-il eu beaucoup de pertes sanguines ou de transferts liquidiens (par ex., $>4$ culots globulaires)?

- Dans les cas de fracture de la colonne cervicale, est-il possible qu'il y ait un hématome paravertébral qui pourrait compromettre le calibre des voies aériennes?

- A-t-on besoin d'un examen neurologique urgent, ou puis-je retarder l'extubation?

Facteurs liés au patient

- Comorbidités cardiopulmonaires importantes?

- Obésité morbide?

Facteurs liés à l'anesthésie

- L'intubation a-t-elle été difficile ou traumatique au début du cas?

- Y a-t-il des antécédents d'intubation difficile?

- Quelle est la gravité de l'œdème facial, de la langue et/ou des voies aériennes?

- Le patient est-il actuellement stable hémodynamiquement?

- Le bloc neuromusculaire du patient est-il complètement neutralisé?

- Sera-t-il difficile de le ventiler au masque après l'extubation?

- Sera-t-il difficile de le réintuber après l'extubation?

- Y a-t-il du personnel qualifié à disposition pour aider à réintuber la trachée de ce patient?

Facteurs liés au matériel

Est-ce que je dispose d'un échangeur de sonde trachéale?

Est-ce que je dispose de dispositifs pour les voies aériennes de rechange en salle d'opération (SO) (par ex., dispositif supraglottique, bronchoscope à fibre optique, GlideScope $\left.{ }^{\circledR}\right)$ ?

Vérifier la perméabilité des voies aériennes

- Réaliser une laryngoscopie directe pour évaluer l'ampleur de l'œdème des voies aériennes supérieures.

- La réalisation d'un essai d'étanchéité autour de la sonde endotrachéale (SET) lorsque le ballonnet est dégonflé peut aider à déterminer la probabilité de réussite de l'extubation chez un patient respirant spontanément. Toutefois, ce type d'essai se concentre sur l'évaluation de l'œdème laryngé et pourrait donc ne pas être utile en cas d'œdème de la langue ou supraglottique.

Ossai d'étanchéité à pression positive: pendant l'insufflation des poumons, dégonfler le ballonnet témoin et écouter pour détecter toute fuite d'air autour de la SET. Il devrait y avoir fuite d'air lors de pressions inférieures à $15-20 \mathrm{~cm} \mathrm{H}_{2} \mathrm{O}$. Afin de mesurer les pressions d'insufflation hors de la SO, insérer un manomètre dans le circuit patient. Autrement, lors de l'insufflation des poumons, utiliser un spiromètre pour observer les différences entre les volumes courants inspiré et expiré avec le ballonnet témoin dégonflé. Si la différence est $>110 \mathrm{~mL}$, il s'agit d'une indication raisonnable que les voies aériennes sont perméables.

Essai d'étanchéité à pression négative: dégonfler le ballonnet témoin, détacher la SET du circuit et bloquer simultanément la SET; observer s'il y a mouvement respiratoire. S'il n'y a pas de mouvement respiratoire, l'essai a échoué.

- Ultrason (US)

L’US pourrait aider à évaluer le diamètre de la colonne d'air dans le larynx.

Prise en charge des cas équivoques

- Préparer le matériel de réintubation et demander à du personnel qualifié d'être à votre disposition pour une éventuelle réintubation.

- Extuber en maintenant l'échangeur de sonde trachéale en place (les échangeurs de sonde sont en général bien tolérés).

- Retarder l'extubation pour permettre à l'œdème de se résorber. Si possible, placer le patient dans une position avec la tête en haut; envisager l'administration de diurétiques et de dexaméthasone avant la prochaine tentative d'extubation.

différences clés dans la façon de réaliser un massage cardiaque externe et la défibrillation chez un patient placé sur le ventre.

Les résultats de deux petites études cliniques ont montré que le massage cardiaque externe en position ventrale pouvait provoquer une tension artérielle systolique et diastolique légèrement supérieure comparativement à celle observée en décubitus dorsal. ${ }^{29,30}$ Bien qu'il n'existe pas de données probantes concluantes ou de consensus concernant la meilleure façon de procéder pour réanimer un patient en position ventrale, il est communément admis que la réanimation devrait être entreprise immédiatement, avant de couvrir le site chirurgical et de retourner le patient sur le dos. Le massage thoracique peut être réalisé sur la colonne thoracique postérieure, entre les omoplates. On peut 
appliquer une contre-pression (par ex. en plaçant un poing sous le sternum) chez les patients positionnés à l'aide de traversins, de rembourrage ou sur une table de Jackson (figure 1). L'efficacité du massage thoracique peut être réduite chez les patients placés sur un pont de Wilson ou un pont de Montréal (Montreal frame) en raison de l'accès limité pour pratiquer une contre-pression. ${ }^{31,32}$

Des palettes de défibrillation peuvent être placées en position antérieure-postérieure; toutefois, on ne connaît pas l'impact de cette manœuvre sur l'impédance ou sur l'efficacité de la défibrillation (ou de la cardioversion). Chez les patients présentant un risque de dysrythmies cardiaques peropératoires élevé, comme par ex. ceux ayant des antécédents d'arythmie ventriculaire, les palettes de défibrillation devraient être placées dans les positions sternales et apicales habituelles avant le positionnement ventral. Lorsque le patient est retourné sur le dos, le massage cardiaque sera temporairement interrompu et il est possible que les moniteurs doivent être déconnectés. La décision de tourner le patient sur le dos pendant la réanimation devrait se fonder principalement sur l'efficacité du massage cardiaque externe et de la défibrillation (ou de la cardioversion) en position ventrale. Parmi les autres éléments dont il faut tenir compte, citons la durée prévue d'interruption de la réanimation pendant le repositionnement, le besoin d'accès à d'autres interventions de réanimation (par ex., l'insertion d'un drain thoracique, une péricardiocentèse, une canulation artérielle ou veineuse centrale), et l'état de la lésion chirurgicale (par ex., de nombreux instruments chirurgicaux in situ).

\section{Les complications au niveau des voies aériennes}

De nombreuses complications ont été rapportées en rapport avec la sonde endotrachéale chez des patients en position ventrale, notamment une coudure de la sonde, son obstruction par des sécrétions, sa migration vers la carène ou une bronche, ou encore le délogement de la sonde hors de la trachée du patient. Étant donné que la sonde peut se plier et former un coude pendant l'hyperflexion du cou, il faut peut-être envisager dans ces situations une sonde renforcée plutôt qu'une sonde standard. Les inconvénients d'une sonde renforcée sont l'incapacité de couper le tube, un diamètre interne plus petit, l'obstruction de la sonde par morsure si on ne prend pas des précautions appropriées, et un rétrécissement persistant de la sonde si elle se déforme (à cause du fil de fer protecteur dans sa paroi). Diverses pièces buccales disponibles sur le marché peuvent réduire l'obstruction de la sonde endotrachéale provoquée par les dents et prévenir une protrusion de la langue entre les dents, mais plusieurs modèles sont rigides et peuvent provoquer une ulcération des palais durs et mous ainsi qu'un œdème de la langue en raison d'une congestion veineuse et lymphatique. Des «blocs » de gaze placés horizontalement entre les dents peuvent aussi réduire le risque d'obstruction de la sonde due aux morsures et à la protrusion de la langue. ${ }^{33}$

\section{L'extubation accidentelle}

L'extubation trachéale accidentelle, lorsque le patient est en position ventrale, peut constituer une complication catastrophique. Même si l'intubation trachéale était facile en décubitus dorsal, il faut présumer dans un tel scénario que le rétablissement des voies aériennes représentera un défi de taille et ce, pour plusieurs raisons: en premier lieu, le temps pour rétablir les voies aériennes est limité, parce que les réserves d'oxygène sont limitées, particulièrement si la $\mathrm{FiO}_{2}$ durant le maintien de l'anesthésie était $<0,6$. Deuxièmement, les anesthésiologistes n'ont pas l'habitude de ventiler au masque ou de manipuler les voies aériennes lorsque le patient est placé sur le ventre. Troisièmement, les positions de la tête et du cou pourraient être fixées à l'aide de clameaux crâniens (par ex., pendant les chirurgies de la tête postérieure et de la colonne), ce qui limite encore plus l'accès aux voies aériennes. Si la tête du patient n'est pas immobilisée, on peut la tourner de côté pour accéder aux voies aériennes, mais la ventilation au masque pourrait tout de même être difficile en raison de l'angle aigu et de l'étroitesse accrue des voies aériennes. L'ouverture limitée de la bouche et la rotation du cou, ainsi que l'incapacité d'aligner les axes oral, oropharyngé et laryngé rendent le rétablissement des voies aériennes quasi impossible sans avoir recours à de l'équipement et à une assistance experte supplémentaire.

Les techniques utilisées pour prendre en charge une telle complication et rétablir les voies aériennes ont été décrites dans des cas publiés d'extubation accidentelle. ${ }^{34}$ La figure 2 résume une approche générale. Dans les cas où la sonde endotrachéale n'est ressortie que de quelques centimètres seulement, il est parfois possible de la réinsérer entre les cordes vocales. Si toutefois la sonde est complètement ressortie de la trachée, il s'agit d'une urgence critique et le temps est compté avant la survenue d'une hypoxémie grave. Il convient alors de tout faire pour apporter au plus vite un brancard en SO afin de retourner immédiatement le patient sur le dos sur le brancard et de sécuriser les voies aériennes du patient dans cette position.

L'insertion d'un dispositif supraglottique pourrait améliorer l'oxygénation du patient pendant que le brancard et l'équipement destiné aux intubations difficiles sont apportés en SO. Un dispositif supraglottique, comme un masque laryngé par exemple, semble être l'outil de choix pour le sauvetage des voies aériennes. Ce choix se 
fonde sur des comptes rendus relatant sa facilité relative d'insertion en position ventrale et les taux élevés de réussite de l'intubation. ${ }^{32}$ Toutefois, l'insertion d'un dispositif supraglottique peut s'avérer complexe chez un patient obèse, et la réussite du positionnement peut être mise à mal par une rotation latérale limitée de la tête et du cou en position ventrale. Dans un compte rendu de 12 études dans lesquelles on a entrepris l'insertion non urgente d'un dispositif supraglottique chez des patients déjà placés en position ventrale, le taux de réussite de l'insertion était de $88-100 \%$ lors de la première tentative et de $100 \%$ avec une seconde tentative et ce, dans toutes les études. ${ }^{13,34}$ Selon une autre étude comparant la facilité d'insertion de différents types de dispositifs supraglottiques chez des patients placés en position ventrale, les masques laryngés LMA-Classic $^{\mathrm{TM}}$, LMA-Proseal ${ }^{\mathrm{TM}}$ et LMA-Supreme ${ }^{\mathrm{TM}}$ (LMA North America, San Diego, CA, États-Unis) ont tous donné des résultats semblables. ${ }^{35}$

\section{L'embolie gazeuse veineuse}

Des cas d'embolie gazeuse veineuse (EGV) ont été rapportés pendant les chirurgies du rachis en position ventrale. Étant donné que le site chirurgical est au-dessus du niveau du cœur, des pressions sous-atmosphériques peuvent potentiellement se développer et entraîner de l'air dans le système veineux. Cette complication est heureusement peu fréquente, étant donné que la pression veineuse de la plupart des patients en position ventrale est légèrement élevée en raison de la compression abdominale. Nous ne connaissons pas la véritable incidence d'EGV, mais plus de 30 cas ont été rapportés dans la littérature depuis les années 1960, la majorité se concluant par le décès ou des complications hémodynamiques graves. L'EVG sous-clinique pourrait être plus fréquente qu'on ne le pense, étant donné qu'il n'y a habituellement pas de monitorage de l'EVG en position ventrale. ${ }^{1} \mathrm{~L}$ 'approche pour le diagnostic et la prise en charge de l'EVG chez un patient placé en position ventrale est semblable à celle d'un patient sur le dos, hormis le fait que la réanimation est plus difficile en position ventrale.

\section{Les lésions et complications liées à la pression}

Les lésions et complications liées à la pression en position ventrale sont abondamment rapportées dans la littérature médicale; elles peuvent affecter pratiquement tous les organes, de la tête aux pieds. La plupart de ces situations surviennent malgré nos meilleurs efforts pour placer le patient de façon optimale. Les lésions à la peau et aux tissus mous sont les plus fréquentes, allant de légères abrasions de la peau à des hématomes en passant par l'apparition d'ampoules et de nécrose. Parmi les autres lésions liées à la pression fréquemment rapportées, citons celles aux organes externes tels que les seins et les organes génitaux externes, mais il peut également y avoir des lésions aux organes viscéraux, comme par exemple l'apparition d'une pancréatite aiguë ou d'une insuffisance hépatique aiguë. ${ }^{36}$ Malheureusement, la plupart des complications liées à la position ventrale apparaissent dans la littérature sous forme de cas isolés ou de petites séries de cas; l'incidence exacte de ces lésions et complications liées à la pression est donc difficile à déterminer. En effet, la nature sporadique des incidents rapportés nous laisse soupçonner que bon nombre d'autres lésions surviennent mais ne le sont pas.

Les lésions aux nerfs périphériques, telles que des paralysies des nerfs du plexus brachial ou du nerf cubital, ont également été rapportées suite à un positionnement ventral. On croyait traditionnellement que les neuropathies postopératoires étaient exclusivement provoquées par une compression directe des nerfs périphériques. De nos jours, on reconnait que les comorbidités des patients, les facteurs chirurgicaux (par ex., une durée de chirurgie prolongée), et les réactions inflammatoires systémiques périopératoires jouent tous des rôles importants dans l'apparition des neuropathies périopératoires. ${ }^{37}$ Le monitorage peropératoire des potentiels évoqués somesthésiques (PES) pourrait dépister les complications nerveuses. Toutefois, il n'existe pas suffisamment de données probantes pour recommander l'utilisation systématique des PES afin de détecter les lésions liées à la position ventrale, bien qu'une étude ait observé que $7 \%$ des patients en position ventrale (c.-à-d. en position de 'Superman') avaient démontré des changements de leurs PES dans les membres supérieurs et que, suite au repositionnement du membre affecté, aucun de ces patients n'avait démontré de déficit neurologique postopératoire. $^{38}$ Malheureusement, les signes et symptômes de lésions nerveuses liées au positionnement peuvent n'apparaître que trois semaines après la chirurgie, ce qui explique en partie pourquoi ces lésions sont sous-rapportées. Une simple évaluation postopératoire de la fonction nerveuse périphérique pourrait néanmoins améliorer la détection et la prise en charge précoce de ces neuropathies. Si on soupçonne qu'un patient pourrait souffrir d'une neuropathie périphérique liée à la position, la prise en charge initiale devrait inclure un historique détaillé des symptômes et la réalisation d'un examen neurologique complet. L'objectif est d'identifier le site de la lésion (par ex. lésion au nerf distal vs au plexus brachial proximal) et d'exclure les autres causes, comme par exemple un accident vasculaire cérébral. Des tests supplémentaires tels que neuro-imagerie, conduction nerveuse ou études électromyographiques pourraient également être utiles. Nous recommandons une 
consultation formelle en neurologie pour effectuer une évaluation détaillée et un suivi approprié des neuropathies périopératoires.

\section{La perte de la vision après chirurgie}

La perte de la vision est une complication rare mais catastrophique de la chirurgie en position ventrale. ${ }^{39}$ Dans une étude américaine nationale menée entre 1996 et 2005, la prévalence de cette complication a été rapportée chez 3,1 patients sur 10000 après une chirurgie rachidienne en position ventrale. ${ }^{40}$ D'autres études rétrospectives d'envergure rapportent une incidence allant de 0,028 \% dans la base de données Johns Hopkins de 14102 cas rachidiens à $0,2 \%$ dans une étude portant sur 3450 cas rachidiens. ${ }^{41-43}$ En raison de la faible incidence de perte de vision après chirurgie, aucune étude observationnelle prospective d'envergure n'a été publiée. Le registre de cette complication de l'American Society of Anesthesiologists ${ }^{44}$ cite la neuropathie optique ischémique (NOI) comme cause la plus fréquente de perte de vision après une chirurgie du rachis ( 83 des 93 cas de perte de vision). Les autres causes de cette complication, notamment l'occlusion de l'artère centrale de la rétine, la cécité corticale, les lésions orbitaires directes, le décollement rétinien et le glaucome aigu, devraient toutes être envisagées chez les patients présentant une baisse de l'acuité visuelle après chirurgie (tableau 4). Une perte sanguine de plus de $1000 \mathrm{~mL}$ et une durée d'anesthésie supérieure à six heures ont été identifiées comme des facteurs de risque importants de NOI. ${ }^{45}$ Dans une étude cas-témoins récente portant sur 80 patients atteints de NOI et 315 témoins appariés, le sexe masculin, l'obésité, l'utilisation d'un pont de Wilson et une chirurgie prolongée se sont avérés des facteurs de risque indépendants de perte de vision après chirurgie, alors que l'utilisation de colloïdes s'est révélée être un facteur de protection. ${ }^{46}$ Un compte rendu récent des facteurs causatifs de cette complication offre d'excellentes illustrations et vidéos. ${ }^{39}$ Tous les patients souffrant de perte de vision après chirurgie doivent être urgemment référés à un ophtalmologiste. Des mesures générales afin de réduire l'incidence de cette complication (qui ne sont pas spécifiques à la position ventrale) sont résumées dans le tableau 5.

\section{Stratégies pour améliorer la sécurité des patients subissant une chirurgie en position ventrale}

Recommandations générales

La préparation pour le positionnement ventral est une tâche laborieuse. Trois éléments majeurs sont requis avant de placer un patient sur le ventre (figure 3): évaluation et préparation adaptées du patient, vérification de l'équipement, et garantie de la disponibilité de personnel qualifié. L'équipement utilisé pour le positionnement doit être régulièrement mis à jour et soumis à des contrôles de sécurité. Après avoir positionné le patient sur le ventre, un examen méticuleux du patient doit être réalisé de façon systématique afin de minimiser les complications liées à la position (figure 4). Pendant la chirurgie, il faut vérifier régulièrement les yeux et la bouche du patient, ainsi que les membres, lorsque cela est possible. Le visage et les membres doivent faire l'objet d'un contrôle lors de chaque repositionnement de la table. Une documentation détaillée du positionnement pendant l'anesthésie est essentielle et nécessaire à des fins médicolégales, et elle devrait inclure les précautions spécifiques prises pour minimiser les complications.

La position ventrale est couramment utilisée, mais on continue de rapporter des lésions et des accidents évitables. Le positionnement ne fait que trop rarement l'objet d'une formation formelle du personnel de SO (chirurgiens, anesthésiologistes et personnel infirmier). La formation se fait souvent à la manière des apprentis, soit par une approche « observez bien, puis faites-le ». Dans l'idéal, le positionnement devrait faire partie de la formation en anesthésie et en chirurgie ainsi que de l'orientation du personnel infirmier de SO. Nous recommandons une approche d'équipe structurée et la sélection minutieuse des équipements en fonction du patient et de la chirurgie. L'utilisation méthodique de listes de contrôle (checklists) a également été recommandée afin de guider les équipes de $\mathrm{SO}$ et de réduire les complications liées à la position ventrale. ${ }^{47}$

La divulgation des risques liés au positionnement ventral

Étant donné toutes les complications et lésions potentielles associées à la position ventrale, il est surprenant que le consentement éclairé du patient, incluant une divulgation complète des risques associés, ne soit pas obtenu de façon plus systématique. ${ }^{48}$ Au Royaume-Uni, les résultats d'un sondage national réalisé auprès des anesthésiologistes et portant sur le processus de consentement éclairé lié à la position ventrale ont révélé que seuls $51 \%$ des répondants rapportaient expliquer systématiquement les risques associés à la position ventrale à leurs patients, et seuls 32 $\%$ de ceux-ci documentaient les risques discutés. ${ }^{49}$ Les répondants mentionnaient les risques fréquents et rares, notamment l'enflure faciale, la rougeur au niveau des zones sous pression, les lésions nerveuses périphériques et la perte de vision après chirurgie.

La responsabilité d'obtenir un tel consentement éclairé et de divulguer tous les risques associés au positionnement 
Tableau 4 Causes possibles d'une perte de vision après chirurgie

\begin{tabular}{|c|c|c|c|}
\hline & Physiopathologie & Présentation & Ophtalmoscopie \\
\hline $\begin{array}{l}\text { Neuropathie } \\
\text { optique } \\
\text { ischémique } \\
\text { antérieure }\end{array}$ & $\begin{array}{l}\text { - Lésion ischémique du nerf optique (antérieure à la } \\
\text { lame criblée) en raison d'une occlusion/ } \\
\text { hypoperfusion de la circulation ciliaire postérieure } \\
\text { - Cause la plus fréquente de perte de vision après } \\
\text { une chirurgie cardiaque }\end{array}$ & $\begin{array}{l}\text { - Période lucide de vision } \\
\text { normale (quelques jours) } \\
\text { - Détérioration subite de la } \\
\text { vision, progressant } \\
\text { pendant plusieurs jours } \\
\text { - Généralement bilatérale } \\
\text { - Peut aller d'un déficit du } \\
\text { champ visuel (inférieur) } \\
\text { à une cécité complète }\end{array}$ & $\begin{array}{l}\text { - Disque optique enflé } \pm \text { hémorragies en } \\
\text { forme de flamme ou hémorragies en } \\
\text { éclats en bordure de la papille optique } \\
\text { - Atrophie optique 4-6 semaines après la } \\
\text { lésion }\end{array}$ \\
\hline $\begin{array}{l}\text { Neuropathie } \\
\text { optique } \\
\text { ischémique } \\
\text { postérieure }\end{array}$ & $\begin{array}{l}\text { - Lésion ischémique au nerf optique (postérieure à la } \\
\text { lame criblée) en raison d'une congestion veineuse } \\
\text { - Cause la plus fréquente de perte de vision après } \\
\text { une chirurgie rachidienne }\end{array}$ & $\begin{array}{l}\text { - Survient immédiatement } \\
\text { après la chirurgie } \\
\text { - Généralement bilatérale }\end{array}$ & $\begin{array}{l}\text { - Ophtalmoscopie normale } \\
\text { - Atrophie optique 4-6 semaines après la } \\
\text { lésion }\end{array}$ \\
\hline $\begin{array}{l}\text { Occlusion de } \\
\text { l'artère } \\
\text { centrale de la } \\
\text { rétine }\end{array}$ & $\begin{array}{l}\text { - Compression soutenue directe du globe oculaire } \\
\text { - Associée à un traumatisme périorbitaire }\end{array}$ & $\begin{array}{l}\text { - Survient immédiatement } \\
\text { après la chirurgie } \\
\text { - Généralement unilatérale }\end{array}$ & $\begin{array}{l}\text { - Blanchiment rétinien avec vaisseaux } \\
\text { rétiniens atténués } \\
\text { - Tâche rouge cerise / pourpre dans la } \\
\text { macula (signe pathognomique) }\end{array}$ \\
\hline Cécité corticale & $\begin{array}{l}\text { - Infarctus du lobe occipital provoqué par: } \\
\text { Embolie } \\
\text { Ischémie de la zone des prés (watershed area) } \\
\text { suite à une hypotension peropératoire } \\
\text { significative }\end{array}$ & $\begin{array}{l}\text { - Survient immédiatement } \\
\text { après la chirurgie } \\
\text { - Généralement bilatérale }\end{array}$ & - Normale \\
\hline Glaucome & $\begin{array}{l}\text { - Mécanisme inconnu } \\
\text { On pense qu'il est dû à un blocage pupillaire par } \\
\text { le mouvement vers l'avant de la lentille contre } \\
\text { l'iris pendant le positionnement ventral } \\
\text { La position ventrale peut augmenter davantage } \\
\text { une pression intraoculaire déjà élevée. A été } \\
\text { utilisé comme test de provocation pour dépister } \\
\text { le glaucome aigu }\end{array}$ & $\begin{array}{l}\text { - Douleur intense et vision } \\
\text { floue } \\
\text { - Paupières enflées, œdème } \\
\text { de la conjonctive et de la } \\
\text { cornée }\end{array}$ & - Normale \\
\hline
\end{tabular}

Tableau 5 Mesures pour réduire l'incidence de perte de vision après chirurgie

- Envisager une intervention par étapes si une chirurgie prolongée est prévue, par ex. $>12 \mathrm{~h}$.

- Envisager la position de Trendelenburg inversée (niveau de la tête plus haut que le cœur) et une position neutre du cou pour réduire la congestion veineuse.

- Utiliser un monitorage invasif de la tension artérielle.

- Éviter l'hypotension et l'hypovolémie. Envisager l'utilisation de collö̈des pour maintenir une volémie normale et éviter la perfusion d'importants volumes de cristalloïdes.

- Éviter l'anémie (garder l'hématocrite $>30 \%$ ).

- Vérification des yeux toutes les $30 \mathrm{~min}$ afin de s'assurer qu'ils ne subissent aucune compression directe.

ventral incombe traditionnellement au chirurgien au moment d'obtenir le consentement pour la chirurgie, et il arrive malheureusement que la discussion des risques liés au positionnement soit simplifiée ou omise. L'anesthésiologiste peut, et devrait, contribuer à la divulgation des risques, particulièrement du potentiel d'œdème postopératoire des voies aériennes et d'intubation prolongée. Des informations supplémentaires au patient, distribuées sous forme de pamphlets ou de vidéos, pourraient également contribuer à informer plus pleinement le patient.

\section{Conclusion}

La prise en charge sécuritaire des patients anesthésiés en position ventrale se fonde sur une compréhension exhaustive des changements physiologiques qui surviennent en position ventrale et des facteurs prédisposant les patients aux complications liées à un positionnement ventral. Un âge avancé, un IMC élevé, la présence de comorbidités et la durée de la chirurgie semblent constituer les facteurs de risque les plus 
importants. L'équipe de SO doit être bien préparée, bien connaître l'équipement utilisé, faire très attention lors du positionnement du patient, et être vigilante pendant la chirurgie afin de minimiser les blessures. Si les risques sont excessifs ou si le patient ne tolère pas la position ventrale, il est possible qu'il faille modifier le positionnement ou adopter d'autres positions. L'utilisation de listes de contrôle (checklists) peut aider les anesthésiologistes à réaliser l'intervention en toute sécurité et à prendre en charge les patients en position ventrale.

\section{Cas clinique}

On vous demande d'anesthésier une femme de 72 ans devant subir une décompression non urgente de la colonne lombaire (L2-L5) due à une sténose rachidienne. Ses symptômes comprennent une claudication bilatérale, un engourdissement et une paresthésie dans la distribution L3-L4. Parmi ses antécédents médicaux importants, on note une angine stable, une hypertension contrôlée, et un diabète de type 2 contrôlé par son régime alimentaire. Par le passé, elle a subi sans incident une chirurgie de réparation de la coiffe des rotateurs en raison de la dislocation récurrente de son épaule droite. Son indice de masse corporel est de $40 \mathrm{~kg} \cdot \mathrm{m}^{-2}$. Le neurochirurgien aimerait positionner la patiente sur le ventre sur un pont de Wilson (Wilson frame) et placer sa tête dans un appuie-tête en mousse, ses bras ouverts en croix les coudes fléchis à un angle de $90^{\circ}$ sur des appuie-bras.

\section{Directives pour compléter le module de développement professionnel continu (DPC)}

1. Lisez cet article et les références en gras.

2. Allez à: http://www.cas.ca/Members/CPD-Online et choisissez le module actuel (La position ventrale: une mise à jour).

3. Répondez aux questions à choix multiples portant sur le cas clinique.

4. Une fois que vous aurez répondu à toutes les questions, vous aurez accès aux explications d'experts pour tous les choix possibles.

5. Les participants peuvent réclamer un maximum de quatre heures de DPC pour un total de 12 crédits sous la Section 3 du programme de DPC du Collège royal des médecins et chirurgiens du Canada.

\section{Funding None.}

Conflicts of interest None declared.
Editorial responsibility This submission was handled by Dr. Stéphane Lambert, CPD Editor, Canadian Journal of Anesthesia.

Financement Aucun.

Conflit d'intérêt Aucun.

Responsabilité éditoriale Cet article a été traité par Dr. A. Stéphane Lambert, rédacteur des DPC, Journal canadien d'anesthésie.

\section{References}

1. Edgcombe H, Carter K, Yarrow S. Anaesthesia in the prone position. Br J Anaesth 2008; 100: 165-83.

2. Nyren SR, Radell P, Lindahl SG, et al. Lung ventilation and perfusion in prone and supine postures with reference to anesthetized and mechanically ventilated healthy volunteers. Anesthesiology 2010; 112: 682-7.

3. Petersson J, Ax M, Frey J, Sanchez-Crespo A, Lindahl SG, Mure $M$. Positive end-expiratory pressure redistributes regional blood flow and ventilation differently in supine and prone humans. Anesthesiology 2010; 113: 1361-9.

4. Guerin C, Baboi L, Richard JC. Mechanisms of the effects of prone positioning in acute respiratory distress syndrome. Intensive Care Med 2014; 40: 1634-42.

5. Guerin C, Reignier J, Richard JC, et al. Prone positioning in severe acute respiratory distress syndrome. N Engl J Med 2013; 368: 2159-68.

6. Pelosi P, Croci M, Calappi E, et al. The prone positioning during general anesthesia minimally affects respiratory mechanics while improving functional residual capacity and increasing oxygen tension. Anesth Analg 1995; 80: 955-60.

7. Toyota S, Amaki Y. Hemodynamic evaluation of the prone position by transesophageal echocardiography. J Clin Anesth 1998; 10: 32-5.

8. Dharmavaram S, Jellish WS, Nockels RP, et al. Effect of prone positioning systems on hemodynamic and cardiac function during lumbar spine surgery: an echocardiographic study. Spine (Phila Pa 1976) 2006; 31: 1388-93; discussion 94.

9. Shimizu M, Fujii H, Yamawake N, Nishizaki M. Cardiac function changes with switching from the supine to prone position: analysis by quantitative semiconductor gated single-photon emission computed tomography. J Nucl Cardiol 2015; 22: 301-7.

10. Ideno S, Yamada T, Takeda J. Anesthetic management of a patient with severe aortic stenosis undergoing spine surgery (Japanese). Masui 2013; 62: 721-3.

11. Chacon MM, Hattrup EA, Shillcutt SK. Perioperative management of two patients with left ventricular assist devices presenting for noncardiac surgery in the prone position. A A Case Rep 2014; 2: 70-3.

12. Olsen KS, Petersen JT, Pedersen NA, Rovsing L. Self-positioning followed by induction of anaesthesia and insertion of a laryngeal mask airway versus endotracheal intubation and subsequent positioning for spinal surgery in the prone position: a randomised clinical trial. Eur J Anaesthesiol 2014; 31: 259-65.

13. Ellard L, Wong DT. Should we induce general anesthesia in the prone position? Curr Opin Anaesthesiol 2014; 27: 635-42.

14. Malcharek MJ, Rogos B, Watzlawek $S$, et al. Awake fiberoptic intubation and self-positioning in patients at risk of secondary cervical injury: a pilot study. J Neurosurg Anesthesiol 2012; 24: 217-21. 
15. Douglass J, Fraser J, Andrzejowski J. Awake intubation and awake prone positioning of a morbidly obese patient for lumbar spine surgery. Anaesthesia 2014; 69: 166-9.

16. Tsaousi G, Karakoulas $K$, Nouris $C$, Mitos $G$, Vasilakos D. Effect of prone positioning with thoraco-pelvic supports on respiratory mechanics during spine surgery: 5AP4-3. Eur J Anaesthesiol 2012; 29: 89.

17. Jo YY, Kim JY, Kwak YL, Kim YB, Kwak HJ. The effect of pressure-controlled ventilation on pulmonary mechanics in the prone position during posterior lumbar spine surgery: a comparison with volume-controlled ventilation. J Neurosurg Anesthesiol 2012; 24: 14-8.

18. Yokoyama $M$, Ueda $W$, Hirakawa $M$, Yamamoto $H$. Hemodynamic effect of the prone position during anesthesa. Acta Anaesthesiol Scand 1991; 35: 741-4.

19. Merchant $R$, Chartrand D, Dain $S$, et al. Guidelines to the practice of anesthesia—revised edition 2016. Can J Anesth 2016; 63: 86-112.

20. Biais M, Bernard O, Ha JC, Degryse C, Sztark F. Abilities of pulse pressure variations and stroke volume variations to predict fluid responsiveness in prone position during scoliosis surgery. $\mathrm{Br}$ J Anaesth 2010; 104: 407-13.

21. Wu CY, Lee TS, Chan KC, Jeng CS, Cheng YJ. Does targeted preload optimisation by stroke volume variation attenuate a reduction in cardiac output in the prone position. Anaesthesia 2012; 67: 760-4.

22. Sudheer PS, Logan SW, Ateleanu B, Hall JE. Haemodynamic effects of the prone position: a comparison of propofol total intravenous and inhalation anaesthesia. Anaesthesia 2006; 61: 138-41.

23. Wattenmaker I, Conception M, Hibberd P, Lipson S. Upperairway obstruction and perioperative management of the airway in patients managed with posterior operations on the cervical spine for rheumatoid arthritis. J Bone Joint Surg Am 1994; 76: 360-5.

24. Sinha A, Agarwal A, Gaur A, Pandey CK. Oropharyngeal swelling and macroglossia after cervical spine surgery in the prone position. J Neurosurg Anesthesiol 2001; 13: 237-9.

25. Morita M, Nobuta M, Naruse H, Nakamura H. Prolonged airway obstruction after posterior occipitocervical fusion: a case report and literature review. Adv Orthop 2011; 2011: 791923.

26. Cavallone LF, Vannucci A. Review article: Extubation of the difficult airway and extubation failure. Anesth Analg 2013; 116 : 368-83.

27. Difficult Airway Society Extubation Guidelines Group, Popat M, Mitchell $V$, et al. Difficult Airway Society Guidelines for the management of tracheal extubation. Anaesthesia 2012; 67: 318-40.

28. Cata JP, Saager L, Kurz A, Avitsian R. Successful extubation in the operating room after infratentorial craniotomy: the Cleveland Clinic experience. J Neurosurg Anesthesiol 2011; 23: 25-9.

29. Mazer SP, Weisfeldt M, Bai D, et al. Reverse CPR: a pilot study of CPR in the prone position. Resuscitation 2003; 57: 279-85.

30. Haffner E, Sostarich AM, Fosel T. Successful cardiopulmonary resuscitation in prone position (German). Anaesthesist 2010; 59: 1099-101.

31. Tobias JD, Mencio GA, Atwood R, Gurwitz GS. Intraoperative cardiopulmonary resuscitation in the prone position. J Pediatr Surg 1994; 29: 1537-8.
32. Dequin PF, Hazouard E, Legras A, Lanotte $R$, Perrotin D. Cardiopulmonary resuscitation in the prone position: Kouwenhoven revisited. Intensive Care Med 1996; 22: 1272.

33. Lam AM, Vavilala M. Macroglossia: compartment syndrome of the tongue? Anesthesiology 2000; 92: 1832-5.

34. Abrishami A, Zilberman P, Chung F. Brief review: Airway rescue with insertion of laryngeal mask airway devices with patients in the prone position. Can J Anesth 2010; 57: 1014-20.

35. Lopez AM, Valero R, Hurtado P, Gambs P, Pons M, Anglada T. Comparison of the LMA Supreme ${ }^{\mathrm{TM}}$ with the LMA Proseal ${ }^{\mathrm{TM}}$ for airway management in patients anaesthetized in prone position. Br J Anaesth 2011; 107: 265-71.

36. Kamel I, Barnette R. Positioning patients for spine surgery: avoiding uncommon position-related complications. World $\mathrm{J}$ Orthop 2014; 5: 425-43.

37. Winfree $C J$, Kline $D G$. Intraoperative positioning nerve injuries. Surg Neurol 2005; 63: 5-18.

38. Kamel IR, Drum ET, Koch SA, et al. The use of somatosensory evoked potentials to determine the relationship between patient positioning and impending upper extremity nerve injury during spine surgery: a retrospective analysis. Anesth Analg 2006; 102: 1538-42.

39. Biousse V, Newman NJ. Ischemic optic neuropathies. $\mathbf{N}$ Engl J Med 2015; 372: 2428-36.

40. Shen $Y$, Drum $M$, Roth $S$. The prevalence of perioperative visual loss in the United States: a 10-year study from 1996 to 2005 of spinal, orthopedic, cardiac, and general surgery. Anesth Analg 2009; 109: 1534-45.

41. Newman NJ. Perioperative visual loss after nonocular surgeries. Am J Ophthalmol 2008; 145: 604-10.

42. Chang SH, Miller NR. The incidence of vision loss due to perioperative ischemic optic neuropathy associated with spine surgery: the Johns Hopkins Hospital Experience. Spine 2005; 30: 1299-302.

43. Stevens WR, Glazer PA, Kelley SD, Lietman TM, Bradford DS. Ophthalmic complications after spinal surgery. Spine 1997; 22: 1319-24.

44. Lee LA, Roth S, Posner KL, et al. The American Society of Anesthesiologists Postoperative Visual Loss Registry: analysis of 93 spine surgery cases with postoperative visual loss. Anesthesiology 2006; 105: 652-9.

45. Lee LA, Newman NJ, Wagner TA, Dettori JR, Dettori NJ. Postoperative ischemic optic neuropathy. Spine (Phila Pa 1976) 2010; 35: S105-16.

46. Postoperative Visual Loss Study Group. Risk factors associated with ischemic optic neuropathy after spinal fusion surgery. Anesthesiology 2012; 116: 15-24.

47. Salkind EM. A novel approach to improving the safety of patients undergoing lumbar laminectomy. AANA J 2013; 81: 389-93.

48. Nguyen-Lu N, Reddy U, Luoma A. To prone or, not to prone? What are we telling our patients? An audit on documentation of consent for prone positioning during neurosurgery. J Neurosurg Anesthesiol 2012; 24: 495 (abstract).

49. Smith $M$, Klepsch $P$. Consent for prone positioning-a project. Anaesthesia 2014; 69: 205 (abstract). 